\title{
State of Art of Using Biofuels in Spark Ignition Engines
}

\author{
Ashraf Elfasakhany
}

Citation: Elfasakhany, A. State of Art of Using Biofuels in Spark Ignition

Engines. Energies 2021, 14, 779. https://doi.org/10.3390/en14030779

Received: 25 December 2020

Accepted: 29 January 2021

Published: 2 February 2021

Publisher's Note: MDPI stays neutral with regard to jurisdictional claims in published maps and institutional affiliations.

Copyright: (C) 2021 by the author. Licensee MDPI, Basel, Switzerland. This article is an open access article distributed under the terms and conditions of the Creative Commons Attribution (CC BY) license (https:// creativecommons.org/licenses/by/ $4.0 /)$.
Mechanical Engineering Department, College of Engineering, Taif University, P.O. Box 11099, Taif 21944, Saudi Arabia; ashr12000@yahoo.com or a.taha@tu.edu.sa; Tel.: +966-(02)-7272-020; Fax: +966-(02)7274-299

\begin{abstract}
Biofuels are receiving increased scientific attention, and recently different biofuels have been proposed for spark ignition engines. This paper presents the state of art of using biofuels in spark ignition engines (SIE). Different biofuels, mainly ethanol, methanol, i-butanol-n-butanol, and acetone, are blended together in single dual issues and evaluated as renewables for SIE. The biofuels were compared with each other as well as with the fossil fuel in SIE. Future biofuels for SIE are highlighted. A proposed method to reduce automobile emissions and reformulate the emissions into new fuels is presented and discussed. The benefits and weaknesses of using biofuels in SIE are summarized. The study established that ethanol has several benefits as a biofuel for SIE; it enhanced engine performance and decreased pollutant emissions significantly; however, ethanol showed some drawbacks, which cause problems in cold starting conditions and, additionally, the engine may suffer from a vapor lock situation. Methanol also showed improvements in engine emissions/performance similarly to ethanol, but it is poisonous biofuel and it has some sort of incompatibility with engine materials/systems; its being miscible with water is another disadvantage. The lowest engine performance was displayed by n-butanol and i-butanol biofuels, and they also showed the greatest amount of unburned hydrocarbons (UHC) and CO emissions, but the lowest greenhouse effect. Ethanol and methanol introduced the highest engine performance, but they also showed the greatest $\mathrm{CO}_{2}$ emissions. Acetone introduced a moderate engine performance and the best/lowest $\mathrm{CO}$ and UHC emissions. Single biofuel blends are also compared with dual ones, and the results showed the benefits of the dual ones. The study concluded that the next generation of biofuels is expected to be dual blended biofuels. Different dual biofuel blends are also compared with each other, and the results showed that the ethanol-methanol (EM) biofuel is superior in comparison with n-butanol-i-butanol (niB) and i-butanol-ethanol (iBE).
\end{abstract}

Keywords: biofuels; single blends; dual blends; spark ignition engines (SIE)

\section{Introduction}

The world is on the edge of an energy crisis, due to limited energy sources along with ever-increasing energy demand [1]. Statistics show that energy needs will increase by about $50 \%$ in 2025 . Currently, the available sources of energy mainly depend on fossil fuel, which is limited with a non-renewable capability. The main sources of energy are oil (32\%), coal (27\%), and natural gas (22\%) [2]. The problems of environmental pollution and global warming, related to fossil fuels, as well as the oscillation of oil prices can significantly support searching for alternative fuels for the future. Among the most promising alternatives, biofuels are recommended [3]. Biofuels are fuels produced from bio-origin sources, such as biomass.

Biofuels were used in the early decades of the last century but due to the low price of fossil fuels, biofuels were limited in entering into commercial play. Historically, at the beginning of the Second World War, biofuels, especially alcohols, were reused as fuel sources. Later on, in the beginning of the seventies of the last century, an oil crisis was revealed where the gulf countries refrained from exporting oil [2]. This led to a steep rise in the crude oil price, whereby the price of a barrel increased from USD 3 to USD 45. 
This, in turn, led to the world being directed towards biofuels again [4]. Currently, several countries are using biofuels; in particular, the largest biofuel-producing countries are the United States of America, Brazil, China, and India, respectively, due to their benefits, as discussed later [5].

Despite the benefits of biofuels as a renewable source of energy, especially the reductions in greenhouse gases emissions and global warming, in comparison with fossil fuels, biofuels represent less than $1 \%$ of the global market for automobile fuels, and such biofuels depend strongly on governmental support [6,7]. Many countries have started to take serious steps toward producing and using biofuels as a main source of energy in their different energy applications, in order to meet the jump in their energy needs and reduce their imported energy dependency. In particular, Brazil is one of the leading countries in the production of biofuels, where $30 \%$ of the biofuels are used in its transport trucks [8]. The United States, for example, plans to replace 30\% of liquid oil with biofuels in 2025 [6]. India increased biofuel rates from $5 \%$ to $20 \%$ [9]. India plans to reduce its dependency on oil by $10 \%$ in 2022 [10]. The European Union (EU) countries increased their dependency on biofuels [11]. Biofuel production doubled from 2003 to 2017 in some EU countries. The biggest producers of ethanol in the EU are Germany, France, and Poland. The greatest biofuel consumers in the EU are considered in Latvia (31.2\%), Finland (26.7\%) and Sweden $(24.8 \%)$ [12]. China aims to increase its biofuel production capacity from $76 \mathrm{Mt}$ in 2015 to $152 \mathrm{Mt}$ in 2030 [13].

Biofuels are currently among the most important sources of renewable fuels, unlike other natural sources such as petroleum, coal, and other fossil fuels. Biofuels could be derived from plants and animal wastes (mostly horse and cow manures). The agricultural residues are also used for biofuels production. In detail, there are several sources of biofuels from agricultural residues, such as coconut and palm oils $[14,15]$. There are also available sources such as sunflower seeds, soybeans, peanuts, cones, wheat, sugar beet and maize $[16,17]$. In general, biofuels can be produced from dedicated crops, also called energy crops, or from wastes produced by agro-industry and agriculture, or from food waste or food by-product wastes. Biofuels are generated by a series of biological processes, such as hydrolysis, fermentation, and microbiological enzymes, which convert sugar molecules into fuels. Using such methods, hydrocarbons are extracted from the biomass sources; as such, biofuels are classified as natural organic compounds.

In comparison with fossil fuels, biofuels offer several benefits, as discussed next. Biofuel is a renewable source of energy; it turns the agriculture residues into energy; it makes an efficient use of residues with additional income instead of useless disposal; it helps towards a cleaner environment by turning residues into fuel instead of farmers burning them; and finally, it is an available source of energy in all countries, thus meeting strategy needs [18].

One of the main benefits of biofuels as promising future fuels includes their being carbon-free. Carbon dioxide, which is emitted from biofuels in combustion conditions, is extracted from the atmosphere while plants grow. This means that there is no emission of carbon dioxide in biofuel combustion. Biofuels also include oxygen in their structure, which makes fuel burn more completely, e.g., reduces the fuel pollutant emissions produced from volatile organic compounds $[19,20]$. Biofuels also have a high octane number, which eliminates the need to add lead to increase the octane number of regular fuels, as in the fossil fuel condition [21]. In addition, biofuels are degraded biologically, and are mostly non-toxic fuels [22].

Despite the several benefits of biofuels, as discussed above, there are some drawbacks. One of problems of biofuels is their production from food agriculture sources, such as maize and wheat; this, in turn, leads to an increase in food prices, and that can directly affect the lives of poor people [23,24]. Recently, this problem has been partially solved by imposing domestic legislation to prevent the production of biofuels from food sources, using agricultural and animal residues instead $[25,26]$. One further problem is the increased 
costs of biofuel production; however, this problem gets better with time, and in the near future the price would be competitive with other fuels.

Biofuels are reviewed in the literature, and some studies have focused on biofuel types [27]. McDowall et al. [28] reviewed the future of biofuels. Global production methods of biofuels in recent utilizations were reviewed by Refs. [29-31]. Recent technologies for biofuel productions from different residues were reviewed by Ref. [32]. Biofuel production systems from the modeling point of view were reviewed by Ref. [33]. The future of biofuel as renewable energy sources is reviewed by Refs. [34-36]. In spite of all such review studies, there is still a gap in the reviewing of biofuels [37]. There are few studies focusing on the review of biofuels for Spark ignition engines (SIE) [13]. The current work aims at providing the state of art of using biofuels in spark ignition engines. Different fuels in single and dual blends are reviewed and compared under the same rates and engine conditions (Air to fuel ratio, ignition timing, spark timing, compression ratio, etc.). The benefits and weaknesses of using biofuels in SIE are considered. Future biofuels for SIE and the proposed method(s) to reduce engine pollutant emissions are highlighted. This study may help in evaluating the future of biofuels for SIE, and fill some gaps in the current study of biofuels, i.e., cover some topics not presented in the early review studies.

\section{Biofuels for Spark Ignition Engines}

Spark ignition engines (SIE) generally work based on the principle of receiving a mixture of air and gasoline fuel, compressing it, and igniting it using a spark-plug to produce a high temperature/pressure in the cylinder(s). At the time of the invention of the SIE (at the beginning of the last century), biofuels (from feed energy corps and food) were used as an energy source in the engine [38]. The first use of biofuels (ethanol) was in the 1800s. Later on, in 1826, the scientist Sawmill Morey worked to improve the engine's performance using biofuels/bioethanol [38]. In 1860, the German engineer Nicholas Otto used biofuels (alcohols) in one of his engines [38]. In 1908, Henry Ford designed an engine using biofuels (ethyl alcohol) as an energy source [38]. In 1917, the famous scientist Alexander Graham Bell presented a paper in National Geographic about biofuels (ethanol) [38]. However, due to the low cost of fossil fuels, the using of biofuels was limited. Currently, researchers are directed toward biofuel blend technique. The first time gasoline was mixed with biofuels was in 1930 [38]. Biofuels were in development for the first time as fuels for transportation via a fermentation process of sugars into ethanol [39]. Several countries marketed biofuel blends for use in the SIE, such as Germany, Brazil, the Netherlands, France, United States of America and many other countries [40-42].

Biofuels are generally classified into four generations, according to early studies [43-49]. In the first generation, the biofuels were generated from food energy corps. This led to increased food prices due to food shortages [50] and, accordingly, the world moved into the next generation. In the second generation, the biofuels were from non-food corps, such as wheat, straw, and corn husk. The technology of biofuel production is scarce and complex, which makes biofuel production expensive and, in turn, the third generation was introduced. In the third generation, the biofuels were manufactured from microbial algae and cyanobacteria. In the fourth generation, the biofuels are generated from genetic microorganisms using thermochemical processing of $\mathrm{CO}_{2}$. However, the fourth generation is still under development. In the following is a detailed discussion of using different biofuel blends in spark ignition engines.

\subsection{Ethanol}

Ethanol, which is usually a biomass-grounded renewable fuel (known as bio-ethanol), is formed by the alcoholic fermentation of animal and/or agricultural residues [51,52]. Ethanol is normally produced in two forms: hydrous and anhydrous ethanol. Hydrous ethanol is a wet ethanol, which is usually produced by distillation from organic biomass, and it is $95 \%$ ethanol and 5\% moisture content; the hydrous ethanol is suitable as a fuel when mixed with $15 \%$ petroleum fuel. On the other hand, the anhydrous ethanol is formed 
by drying the wet ethanol (hydrous one); the ethanol content in the anhydrous type is $100 \%$, and it can be used as a fuel alone [53,54]. Ethanol, in both its types, is a colorless liquid fuel with a distinctive odor, and has a chemical formula of $\left(\mathrm{C}_{2} \mathrm{H}_{5} \mathrm{OH}\right)$. It is a lead-free fuel with a volatile composition content, so it should not be exposed to air at storage conditions. Ethanol contains oxygen in its chemical composition and, in turn, it is better than benzene and diesel fuels in combustion engines, especially in high altitude countries/cities where environmental oxygen is low. It has a high self-ignition temperature, in comparison with gasoline and diesel fuels [55]. It is also a nontoxic fuel and safe in drinking and inhalation conditions. It interacts with air during combustion, giving water, so it should be kept away from moisture in storage conditions to avoid reducing the fuel concentration, e.g., decreasing fuel efficiency. Sometimes ethanol is added to lead-free gasoline/diesel to improve fuel properties, such as octane/cetane number, fuel composition, oxygen content, etc. [56]. The oxygen-fueled ethanol has a positive effect on the pollutant emissions, as will be discussed later. Ethanol is known to have a high octane number. Referring to the different types of ethanol, it was noted that wet ethanol has a lower octane number than the dry one. The higher the octane number, the higher the compression ratio in the combustion chamber and the more engine propulsion. Ethanol would be used alone as a fuel (especially anhydrous type), and it could be mixed with gasoline (for both types) at any rate.

The most popular ethanol blend in the SI engine is 10\% ethanol with $90 \%$ gasoline, which is known as E10. Additionally, ethanol $85 \%$ is broadly used (known as E85); this fuel mixture is used in some countries such as the United States, and it requires some changes in the engine, such as spark and ignition timing, AF ratio, etc., and it is known as a flexible-fuel technology (F.F.T) [57,58]. Ethanol blends at rates $24 \%$ and $20 \%$ (known as E22 and E24) are used also in some conditions, such as in Brazil, and they require some changes in the engine as well. Finally, ethanol $100 \%$, known as E100, is alternatively used in Brazil, and it requires major modifications in the engine systems. The investigation of ethanol fuel showed many advantages in terms of engine efficiency, released emissions and high thermal proportions, which led to the development of the widespread use of such a fuel $[59,60]$. This is in addition to the improvement of pollutant levels as the proportion of ethanol to gasoline increases in the mixture [61-63]. However, there are also downsides to using ethanol. For example, it sometimes has a problem in starting the engine in cold weather, due to the evaporation problem [64-66]. Additionally, warm or hot weather may cause so-called steam/vapor lock. This is in addition to the fuel's incompatibility with some parts of the engine's metals $[67,68]$. Ethanol being miscible with water is one of its major drawbacks. However, despite all of these defects, it is currently the most applicable renewable fuel in gasoline engines in many countries of the world $[69,70]$.

\subsection{Methanol}

Methanol, also recognized as methyl alcohol, is a liquid fuel containing the chemical formula $\mathrm{CH}_{3} \mathrm{OH}$. Methanol consists of an "OH" group of alcohols bound to a single carbon atom (often shortened as $\mathrm{MeOH}$ ). The carbon atom, which remains a bonding source, is formed by single carbon atom and triple hydrogen atoms [71,72]. Scientists have recognized that liquid methanol shares an origin word with methane gas. The component "meth" in both fuels refers to the single carbon, which is linked to hydrogen atoms. In methanol, this carbon is accompanied with the alcohol group; but in methane, the carbon is accompanied with four hydrogen atoms.

Methanol, as a fuel, is flammable, colorless, volatile and toxic to humans. Methanol could be generated from biomass (bio-methanol) as well as fossil fuels [73-75]. Traditionally, methanol was produced by the fermentation of bacteria in a cellulose compound found in wood and some supplementary plants [76]. This method led to the formation of methanol, which is deadly to drink, but it is useful as a fuel and as a solvent for scientific and industrialized purposes [77,78]. After the discovery of methanol, researchers began using it as a fuel for racing cars (in pure methanol form). It permitted high speeds, but it also contributed to a catastrophic fire that killed race car drivers in the past. Safety regulations 
are currently in place to regulate the quality of methanol on the basis of the engine's working conditions [79].

Methanol is extremely easy to ignite as a gas, and its fire is almost invisible. Methanol has a high octane rating as an ethanol fuel $[80,81]$. Some studies have looked at the use of methanol in SIE, but much less so than ethanol fuel $[82,83]$. In summary, the studies showed a significant improvement in engine performance and a decrease in pollutant emissions, in comparison with neat gasoline [84-86]. Compared to other biofuels, methanol has some advantages; it has the greatest hydrogen to carbon ration, and accordingly, low emission per energy unit [39]. It has also the greatest heat of evaporation and oxygen content, which enhances fuel combustion and emissions. A comparison between methanol and ethanol biofuels as regards engine performance and contaminant emissions of SIE is discussed afterwards.

\subsection{Butanol}

Recently, butanol $\left(\mathrm{C}_{4} \mathrm{H}_{9} \mathrm{OH}\right)$ as a promising biofuel type has been proposed. There are four different structures of this type, which are 1-butanol, 2-butanol, i-butanol, and t-butanol. The 2-butanol and t-butanol have not been confirmed yet [87], while the 1butanol (also called n-butanol or normal butanol) and i-butanol (also called iso-butanol) were verified to be generated by different methods $[88,89]$. They were also produced commercially, (see, e.g., [90-92]). Accordingly, in the study, we will only present the investigation with these types. The use of n-butanol and i-butanol fuel in SIE showed approximately 39-56\% savings in fossil fuels and could also minimize greenhouse gas emissions by approximately $32-48 \%$ [93]. The possible low hydrocarbon mole fractions and their oxygenated content would support both butanol isomers. The results of using neat and biofuel blends of either $n$-butanol or i-butanol with gasoline for spark ignition engines have been documented in the literature.

In what follows, the early analysis of $n$-butanol is briefly summarized. In the case of the addition of n-butanol, Farkade and Pathre [94] showed higher $\mathrm{CO}_{2}$ and $\mathrm{NOx}$ emissions. Deng et al. [95] investigated 35 vol. percent n-butanol in gasoline; the results showed higher power, combustion efficiency, and fuel consumption, but also higher emissions of $\mathrm{HC}, \mathrm{CO}$, and NOx were obtained. Furthermore, 35 and 30\% n-butanol mixed in gasoline were applied by Deng et al. [96], and the results showed that fuel blends can provide full combustion with a higher knock-resistance. Szwaja and Naber [97] tested n-butanolgasoline blends using 100 to $20 \mathrm{vol}$. percent n-butanol in SIE; the findings showed that, compared to other tested fuels, neat n-butanol has the shortest combustion time and highest peak pressure. Up to $10 \% \mathrm{n}$-butanol in gasoline was investigated by Elfasakhany [98]; the emissions and mixed fuel efficiency were improved for mixed fuels compared to clean gasoline. With changing the spark timing, Dernotte et al. [99] studied 20 to 80 vol. percent $\mathrm{n}$-butanol in gasoline. The findings showed higher $\mathrm{CO}$, lower $\mathrm{HC}$ and no substantial improvement in 40 vol. percent blends; 60 and 80 vol. percent blends introduced higher HC emissions by 18 vol. percent. Yang et al. [100,101] analyzed the efficiency and emissions under cold start working conditions of 10 to 35 vol. percent n-butanol blended in gasoline. The results showed low $\mathrm{CO} / \mathrm{HC}$ emissions, but higher NOx emissions. Engine power is not altered when butanol blends are below 20\%, and cold start output is weak for all fuel blends. Wigg et al. [102] studied pure n-butanol emissions and found three times higher HC emissions; however, compared to clean gasoline, NOx and CO emissions are decreased by $17 \%$ and $12 \%$, respectively. In large engine operating conditions, Martin et al. [103] analyzed n-butanol-gasoline blend emissions and reported lower $\mathrm{CO}$ and HC emissions but higher NOx emissions. The oxidation of $85 \% \mathrm{n}$-butanol blended into gasoline was studied by Dagaut and Togbe [104,105], and the authors presented a chemical kinetic mechanism for fuel mixtures. Furthermore, 60 and 80 vol. percent n-butanol blends were tested by Venugopal and Ramesh [106] and the findings showed a rise in $\mathrm{CO} / \mathrm{HC}$ emissions for both fuel blends. Yacoub et al. [107] examined 22 and 11 vol. percent n-butanol-gasoline blends for each fuel blend with the modification of engine 
working conditions. Both fuel blends show declines in $\mathrm{CO} / \mathrm{HC}$ emissions and a rise in NOx emissions. Gu et al. [108] inspected n-butanol-gasoline blends of 10 to 40 vol. percent; the findings showed a decrease in the $\mathrm{CO}$ and unburned hydrocarbons (UHC) emissions of fuel blends. Park et al. [109] studied the efficiency and emissions of n-butanolgasoline blend-fueled SI engines, and found a reduction in emissions. Additionally, 16\% n-butanol-gasoline blends were tested by Cairns et al. [110], and the results showed comparable brake specific fuel consumption (BSFC) and maximum brake torque (MBT) values for both fuel blends and clean gasoline. Niass et al. [111] researched n-butanolgasoline fuel blends and showed lower emissions of $\mathrm{CO}_{2}$ for fuel blends with higher knock resistance. Gautam and Martin [112,113] analyzed 10\% n-butanol in gasoline, and showed lower emissions of $\mathrm{CO}, \mathrm{CO}_{2}, \mathrm{NOx}$ and $\mathrm{HC}$ for fuel blends of about $16 \%, 18 \%, 5 \%$ and $17 \%$, compared to clean gasoline, respectively. Williams et al. [114] analyzed n-butanolgasoline blends, and the findings showed comparable thermal efficiency, combustion and emissions (with the exception of a reduction in $\mathrm{CO}_{2}$ emissions) for both fuel blends and neat gasoline. Furthermore, 85\% n-butanol-gasoline blends were investigated by Cooney et al. [115] without any tuning conditions, and the results showed no improvement in fuel conversion efficiency at lower engine loads; however, fuel conversion efficiency decreased at higher load conditions by $4 \%$ for fuel blends. The flame velocity of n-butanol is higher than that of gasoline when the combustion timing is changed and, in turn, the faster combustion of $n$-butanol will improve the conversion efficiency of the fuel blends. Using 0, 10 and 15 vol. percent of n-butanol-gasoline blends, Mittal et al. [116] investigated engine efficiency and pollutant emissions; fuel blends can increase engine performance and $\mathrm{HC}$ and $\mathrm{CO}$ emissions. With the addition of n-butanol to gasoline, Pereira et al. [117] showed a faster burning velocity, but the flame growth between biofuel blends and clean gasoline was very similar. Broustail et al. [118] investigated n-butanol-gasoline blends using modified working conditions of the engine; their findings showed a close $12.8 \%$ decrease in $\mathrm{CO}$ emissions for fuel blends. The emissions, efficiency, and combustion of 40, 60 and 80 vol. percent n-butanol-gasoline blends were studied by Venugopal and Ramesh [119] and Broustail et al. [120]. The results showed low emissions of HC and $\mathrm{CO}$ for 40 vol. percent n-butanol; however, relative to clean gasoline, 60 and 80 vol. percent n-butanol showed higher $\mathrm{HC}$ and $\mathrm{CO}$ emissions. Lavoie and Blumberg [121] and $\mathrm{Hu}$ et al. [122] investigated SIE engine efficiency and emissions using n-butanolgasoline blends; their findings reported unchanged but decreased NOx emissions in HC emissions, while BSFC increased marginally with fuel blends. Heywood [123] researched n-butanol-gasoline blends and demonstrated incomplete combustion and elevated fuel blend emissions. At engine speeds from 1000 to $4000 \mathrm{r} / \mathrm{min}$ and loads from 0 to $150 \mathrm{Nm}$, Wallner et al. [124] investigated engine outputs of 0 vol. and 10 vol. percent n-butanolgasoline blends. The results registered higher fuel blend burning velocity, but with little change/improvement in CO, HC and NOx emissions and thermal efficiency. Then, 35\% nbutanol in gasoline and pure gasoline was studied by Feng et al. [125] with the modification of ignition timing for each fuel. Fuel blends recorded a 38.3\% rise in NOx emissions, a $13.8 \%$ decrease in $\mathrm{CO}$ emissions, an $11.8 \%$ decrease in $\mathrm{HC}$ emissions, a $7.7 \%$ increase in $\mathrm{CO}_{2}$ emissions, an $11.5 \%$ decrease in BSFC and a 1.2\% increase in torque. Wigg [126] studied the application of n-butanol-gasoline blends and pure n-butanol biofuel combustion and emission appearances. The results showed twice the HC emission value for neat butanol compared to gasoline; for fuel blends, the results showed a $13.5 \%$ decrease in $\mathrm{CO}$ emissions, a $13.5 \%$ rise in NOx emissions, and a $4 \%$ reduction in $\mathrm{HC}$ emissions.

Heretofore, n-butanol fuel was reviewed and many researches have investigated it. In comparison, iso-butanol fuel has not received the same attention from researchers. The use of i-butanol is studied in spark ignition engines; it is much less prolific than nbutanol, and is summarized in the literature below. At engine speeds of 2600-3400 r/min, Elfasakhany [127] examined engine efficiency and pollutant emissions of 0 to 10 vol. percent i-butanol without any engine tuning conditions. The results registered higher $\mathrm{CO}$ and $\mathrm{HC}$ emissions for fuel blends at speeds above or equal to $2900 \mathrm{r} / \mathrm{min}$, but contrary results 
were obtained at speeds below $2900 \mathrm{r} / \mathrm{min}$; the engine torque, fuel blend volumetric performance, and fuel blend brake power give lower values than with pure gasoline. In contrast to clean gasoline, a lower fuel conversion efficiency was shown for i-butanolgasoline blends [128-133]. Rice et al. [134] analyzed 20 vol. percent i-butanol-gasoline blends, and declared lower HC emissions for the fuel blends; however, as the concentration of i-butanol increases, the HC increases rapidly. BQ et al. [135] tested the engine efficiency of 10, 30 and 50 vol. percent i-butanol-gasoline blends; their findings showed a $5 \%$ to $50 \%$ decrease in engine performance, relative to gasoline, for the fuel blends. In conclusion, in contrast to pure fuel, the results of the i-butanol-gasoline blends show decreases in engine efficiency and an improvement in some engine pollutant emissions.

\subsection{Acetone}

As a novel alternative fuel for compression ignition engines (CIE), acetone $\left(\mathrm{C}_{3} \mathrm{H}_{5} \mathrm{OH}\right)$ has recently been suggested [136-138]. In a couple of publications, the investigation of acetone in SIE was found by the author. Using 0, 3, 7 and 10 vol. percent acetonegasoline blends, Elfasakhany [139] examined SIE pollutant emissions and engine efficiency. Compared to clean gasoline, the findings showed better engine efficiency and lower pollutant emissions for fuel blends; exhaust emissions decreased on average by around $32 \%$ for $\mathrm{CO} 2,43 \%$ for $\mathrm{CO}$ and $33 \%$ for UHC compared to clean gasoline. In addition, engine output emissions varied with engine speeds; fuel mixes, in particular, showed an initial increase in UHC and CO emissions, followed by a steady decrease, while engine speeds increased. At moderate engine speeds (2900-3000 $\mathrm{r} / \mathrm{min}$ ), the peak emissions of blended fuel are seen, but these are still lower than those of clean gasoline. In addition, such fuel also needs further analysis by researchers.

\section{Comparison between Single Biofuel Blends in SIE}

Several biofuels have been proposed as promising alternative fuels for spark ignition engines, as discussed above. These biofuels yield significantly dissimilar performances and emissions results based on their different chemical compositions and structures. Ethanol and methanol showed higher engine performance and lower pollutant emissions, in comparison with neat gasoline. N-butanol and i-butanol, on the other hand, provided lower engine performance than neat gasoline, but butanol fuels showed some other benefits, in comparison with ethanol and methanol. The chemical structure of butanol provides some rewards, in comparison with ethanol and methanol, including its lower vapor pressure, which reduces the tendency toward the vapor lock condition and also enhances the cold engine starting condition. Butanol has a superior fuel economy due to its higher energy density [140-142]; it could be blended with gasoline at higher concentrations without (or with minor) retrofitting engines [143], and it has the capability of using existing gasoline fuel distribution pipelines. N-butanol and i-butanol showed lower tendencies toward solubility in water, upper flash point $\left(29^{\circ} \mathrm{C}\right)$ and boiling point $\left(117.7^{\circ} \mathrm{C}\right)$, which makes such butanol fuels safer to use than ethanol and methanol [144]; n-butanol and i-butanol, additionally, may cause less corrosive effects in engine materials and systems [145-147].

In the literature, Elfasakhany [148] examined the performance and pollutant emissions of SIE using ethanol, methanol, n-butanol, i-butanol, and acetone, at the same blend rates $(3,7$, and $10 \mathrm{vol} . \%)$ and engine working conditions. The comparison focused on the engine emissions via $\mathrm{CO}_{2}, \mathrm{CO}$, and $\mathrm{UHC}$, and performance via volumetric efficiency, brake power, and torque in a wide range of engine speeds from 2600 to $3400 \mathrm{r} / \mathrm{min}$. It is important to define or clarify the physical meaning of volumetric efficiency, engine power, and torque, as follows. Volumetric efficiency (VE) is the real quantity of air flowing into the combustion chamber, compared to extreme conditions. Basically, it is a measure of how full the cylinders are. VE changes based on the environmental conditions, such as air density, temperature, and altitude changes. Engine power is the amount of energy or work obtained from the engine per unit of time. Torque is simply the measure of rotational effort applied on the engine crankshaft by the piston. The results showed that the 
n-butanol and i-butanol provide a significant drop in volumetric efficiency, brake power and torque in comparison with ethanol, methanol, acetone and the neat gasoline, as shown in Figure 1. The greatest engine performance is obtained with ethanol and methanol; in detail, the highest volumetric efficiency is provided by methanol; ethanol can provide the greatest output power and torque from the engine. In conclusion, the lowest engine performance is introduced by n-butanol and i-butanol, in comparison with all test fuels. A moderate engine performance is obtained by acetone (AC). Regarding the pollutant emissions, acetone provided the lowest UHC and CO emissions, but n-butanol and ibutanol showed the highest UHC and CO emissions; in particular, n-butanol presented the highest $\mathrm{CO}$ and i-butanol presented the highest UHC emissions, but these are still lower than the neat gasoline fuel, as shown in Figure 2. The comparison also indicated that nbutanol and i-butanol can provide the lowest greenhouse effect among all test fuels. On the other hand, ethanol and methanol introduced the highest $\mathrm{CO}_{2}$ emissions (even higher than the neat gasoline). In conclusion, in order to get a moderate great output torque, volumetric efficiency and brake power, as well as low $\mathrm{UHC}, \mathrm{CO}_{2}$ and $\mathrm{CO}$ emissions, one should apply AC fuel blends. It is important to highlight that i-butanol and n-butanol showed dissimilar results in engine performance and pollutant emissions, e.g., minor differences. This may be due to the similar chemical compositions of both fuels $\left(\mathrm{C}_{4} \mathrm{H}_{9} \mathrm{OH}\right)$. The slight difference appears due to dissimilar combustion characteristics and flame propagations. Both the fuels are different in terms of heating values, saturation pressures, stoichiometric A/F ratios, boiling points and auto ignition temperatures, as summarized in Table $1[149,150]$. One further difference is the structure of both fuels, whereby i-butanol is branched-chain but $\mathrm{n}$-butanol is a straight-chain. There is a minor difference also in the relative reactivity of the both fuel blends, e.g., most reactive for n-butanol and least reactive for i-butanol [127]. Finally, in the comparison of ethanol- and methanol-gasoline blends, ethanol showed a higher brake power and torque than those of methanol, although the later one (methanol) has a higher volumetric efficiency than the ethanol one. This may refer to the fact that ethanol's heating value is greater than that of methanol by nearly 1.3-fold, as shown in Table 1, and that leads to an increase in the brake power and torque for ethanol blends. Regarding pollutant emissions, methanol presented lower $\mathrm{CO}$ and UHC emissions than the ethanol biofuel, but ethanol showed lower $\mathrm{CO}_{2}$ emissions than methanol fuel. This may refer to the fact that the oxygen content of methanol is much higher than that of ethanol, as shown in Table 1; this without a doubt can enhance methanol's combustion and emissions ( $\mathrm{CO}$ and $\mathrm{UHC}$ ) and, in turn, increase $\mathrm{CO}_{2}$ emission. 


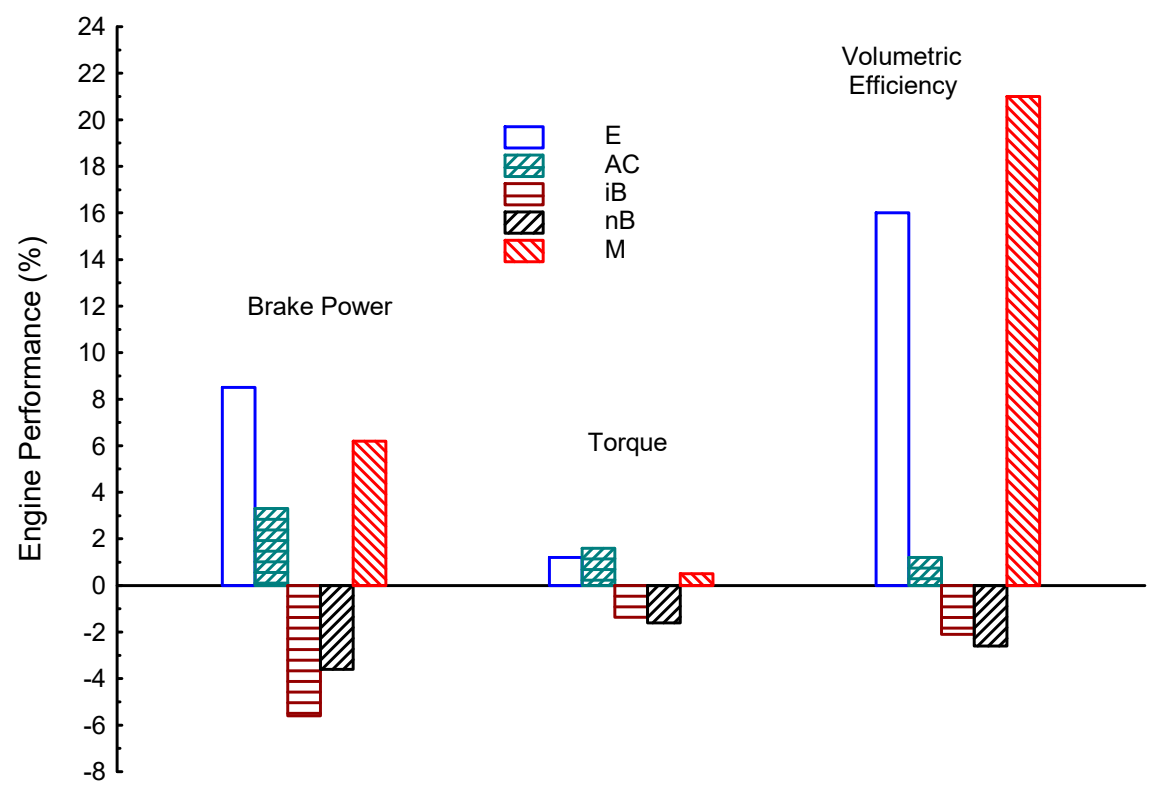

Figure 1. Comparisons of volumetric efficiency, torque, and brake power for ethanol (E), methanol $(\mathrm{M})$, n-butanol (nB), i-butanol (iB), and acetone (AC) blended with gasoline and neat gasoline (baseline) in \%.

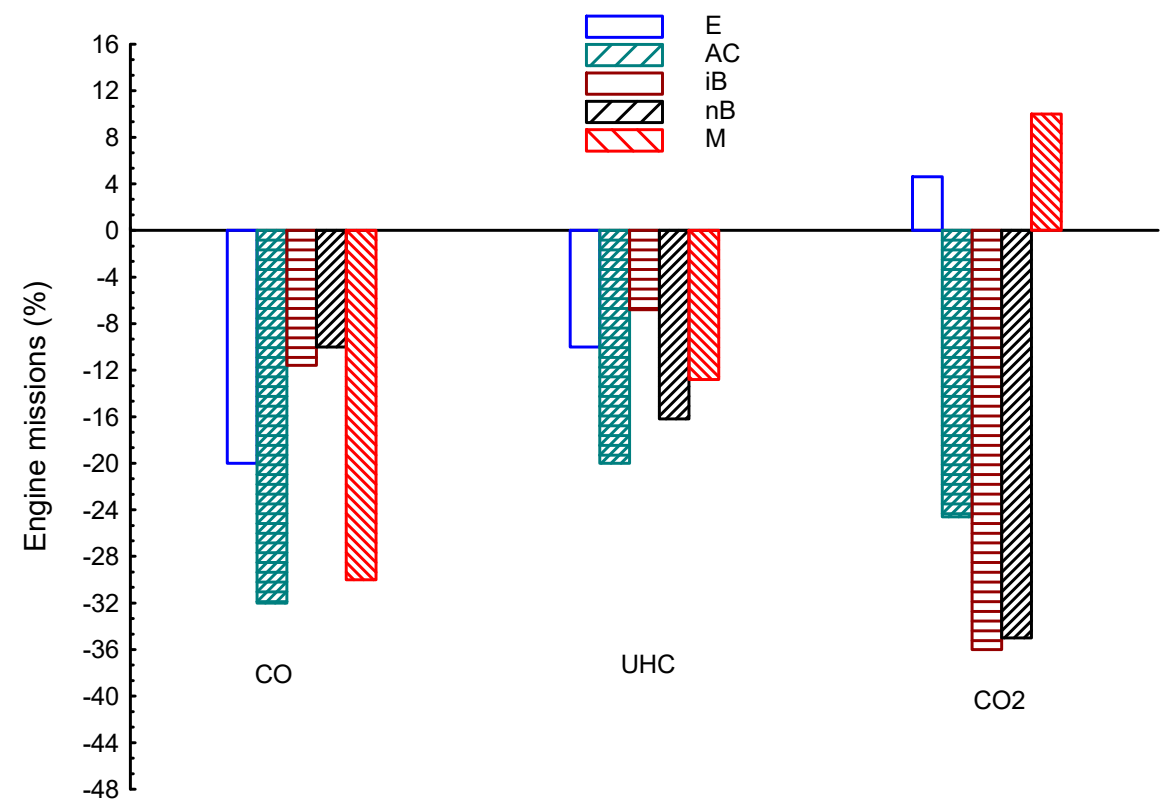

Figure 2. Comparisons of $\mathrm{CO}, \mathrm{CO}_{2}$, and UHC emissions for ethanol (E), methanol (M), n-butanol $(\mathrm{nB})$, i-butanol (iB) and acetone (AC) blended with gasoline and neat gasoline (baseline) in \%. 
Table 1. Properties [149,150].

\begin{tabular}{|c|c|c|c|c|c|c|}
\hline Property & Gasoline & Ethanol & Methanol & I-Butanol & N-Butanol & Acetone \\
\hline Chemical formula & $\mathrm{C}_{8} \mathrm{H}_{15}$ & $\mathrm{C}_{2} \mathrm{H}_{5} \mathrm{OH}$ & $\mathrm{CH}_{3} \mathrm{OH}$ & $\mathrm{C}_{4} \mathrm{H}_{9} \mathrm{OH}$ & $\mathrm{C}_{4} \mathrm{H}_{9} \mathrm{OH}$ & $\mathrm{C}_{3} \mathrm{H}_{5} \mathrm{OH}$ \\
\hline Composition $(\mathrm{C}, \mathrm{H}, \mathrm{O})(\%)$ & $86,14,0$ & $52,13,35$ & $37.5,12.5,50$ & $65,13.5,21.5$ & $65,13.5,21.5$ & $62,10.5,27.5$ \\
\hline Lower H. V (MJ/kg) & 43.5 & 27.0 & 20.1 & 33.3 & 33.1 & 29.6 \\
\hline Heat of evap. (kJ/kg) & 223.2 & 725.4 & 920.7 & 474.3 & 582 & 501.7 \\
\hline Stoichiometric A/F ratio & 14.6 & 9.0 & 6.4 & 11.1 & 11.2 & 9.54 \\
\hline Oxygen content, mass \% & 0.0 & 34.7 & 49.9 & 21.6 & 21.6 & 27.6 \\
\hline Density $\left(\mathrm{kg} / \mathrm{m}^{3}\right)$ & 760 & 790 & 796 & 802 & 810 & 791 \\
\hline Saturation pressure & 31 & 13.8 & 31.69 & 2.3 & 2.27 & 53.4 \\
\hline Flash point $\left({ }^{\circ} \mathrm{C}\right)$ & -45 to -38 & 21.1 & 11.1 & 28 & 35 & 17.8 \\
\hline Auto-ignition temp. $\left({ }^{\circ} \mathrm{C}\right)$ & 420 & 434 & 470 & 415 & 385 & 560 \\
\hline Boiling point $\left({ }^{\circ} \mathrm{C}\right)$ & $25-215$ & 78.4 & 64.5 & 108 & 117.7 & 56.1 \\
\hline Solubility in water & $<0.1$ & Fully miscible & Fully miscible & 10.6 & 7.7 & Miscible \\
\hline Vapor toxicity & Moderate & Very toxic & Toxic & Moderate & Moderate & Low \\
\hline
\end{tabular}

\section{Comparison between Dual Biofuel Blends in SIE}

Different dual blended biofuels are compared to each other in the literature. Elfasakhany [151] examined ethanol-methanol-gasoline, i-butanol-ethanol-gasoline and n-butanol-i-butanolgasoline blends, as shown in Figures 3 and 4. The engine pollutant emissions, performance and combustion characteristics of the three dual blended biofuels are experimentally compared at the same rates and engine working conditions to establish the best prospective one as an alternative to fossil fuel. The results displayed that the engine behavior (volumetric efficiency, output torque, and brake power) were amplified, while engine emissions (unburned hydrocarbons and carbon monoxide) were decreased by using ethanol-methanol-gasoline blends, in comparison with other biofuel blends. However, n-butanol-i-butanol-gasoline blends demonstrated the maximum emissions and the lowermost performances among all tested biofuel blends; i-butanol-ethanol-gasoline blends can offer a reasonable performance and emissions among the three tested biofuel blends. It was also pointed out that the pollutant emissions of all dual biofuel blends are lower than the pure gasoline. Nonetheless, the engine performances of $n$-butanol-i-butanol-gasoline and i-butanol-ethanol-gasoline blends are inferior to pure gasoline, while ethanol-methanolgasoline displayed a better performance than the pure gasoline. Elfasakhany [152] has examined, for the first time in internal combustion engines, a few new blended biofuels as possible alternatives to fossil fuels. I-butanol was blended in one fuel blend (iBM) with bio-methanol, and gasoline and n-butanol were blended in the other, with bio-ethanol and gasoline (nBE) at rates of 3-10 vol. percent of biofuels for both dual blends. As presented in Figures 5 and 6, the two dual blended biofuels for the engine pollutant emissions and combustion efficiencies in an SIE were contrasted with each other, as well as with pure gasoline. The results specified that, relative to conventional pure gasoline fuel, the two biofuel blends tested can achieve the objective of supplementary green sustainability. IBM fuel blends, which are $31 \%, 19 \%$ and $32 \%$ lower than pure gasoline for $\mathrm{CO}, \mathrm{CO}_{2}$ and $\mathrm{UHC}$ emissions, respectively, obtained the most superior/best engine emissions. Nevertheless, when using plain gasoline, there are trivial advantages in engine efficiency over both iBM and nBM dual biofuel blends. The study also emphasizes that the combination of i-butanol-bio-methanol with gasoline results in higher engine efficiency than the combination of n-butanol-bio-ethanol with gasoline by about $6.2,0.9,2.6$ and $1.47 \%$, for in-cylinder pressure (ICP), exhaust gas temperature (EGT), brake power (BP) and torque (Torq), respectively. The nBE blended biofuel showed a slight decrease in engine performance, in comparison with pure gasoline, by approximately 3.4, 2.4, 5, 1.9 and 5.2\% for EGT, volumetric efficiency (VE), ICP, Torq and BP, respectively. 


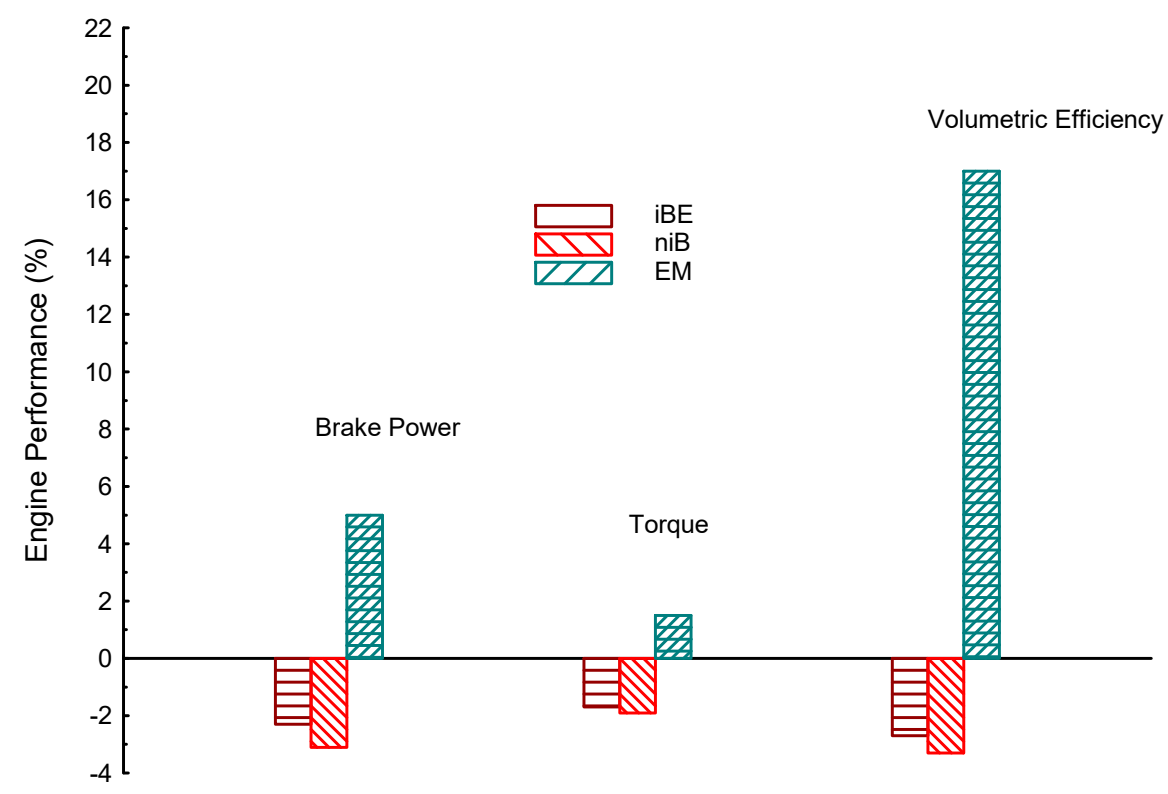

Figure 3. Comparisons of brake power, volumetric efficiency, and torque for ethanol-methanol (EM), n-butanol-i-butanol (niB) and ethanol-i-butanol (iBE) blended with gasoline and neat gasoline (baseline) in \%.

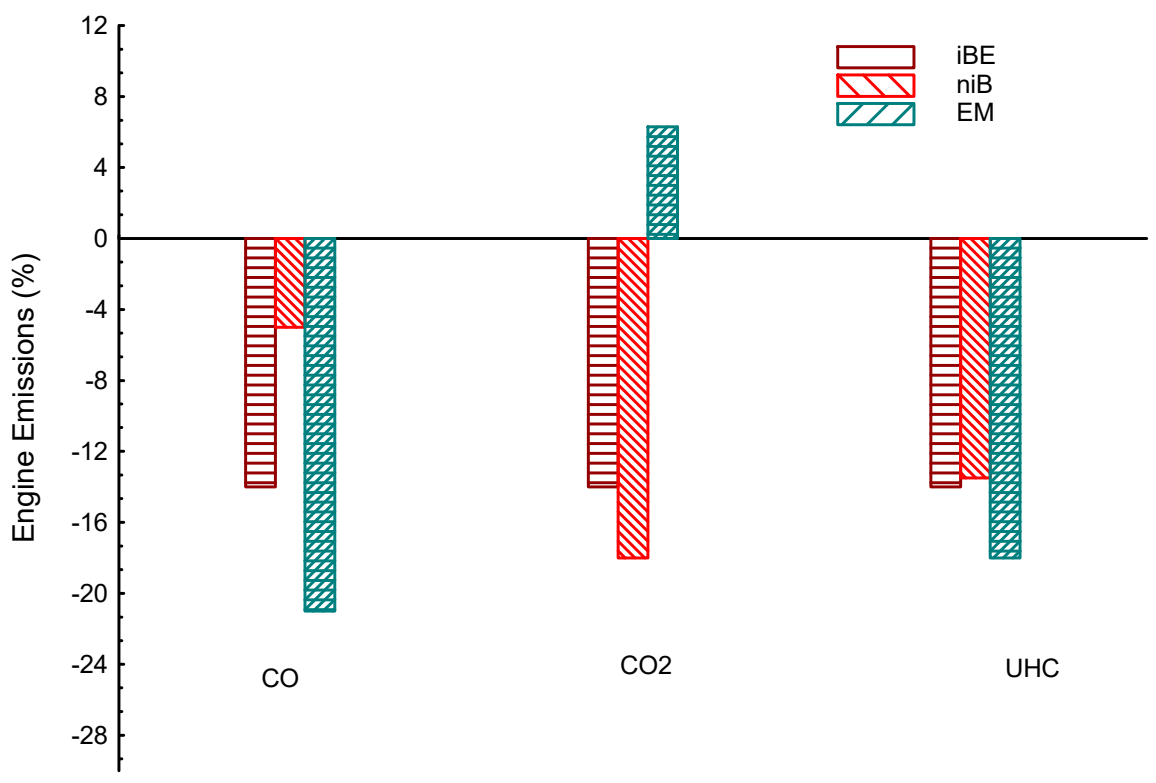

Figure 4. Comparisons of $\mathrm{CO}, \mathrm{CO}_{2}$, and UHC emissions for ethanol-methanol (EM), n-butanoli-butanol (niB) and ethanol-i-butanol (iBE) blended with gasoline and neat gasoline (baseline) in \%. 


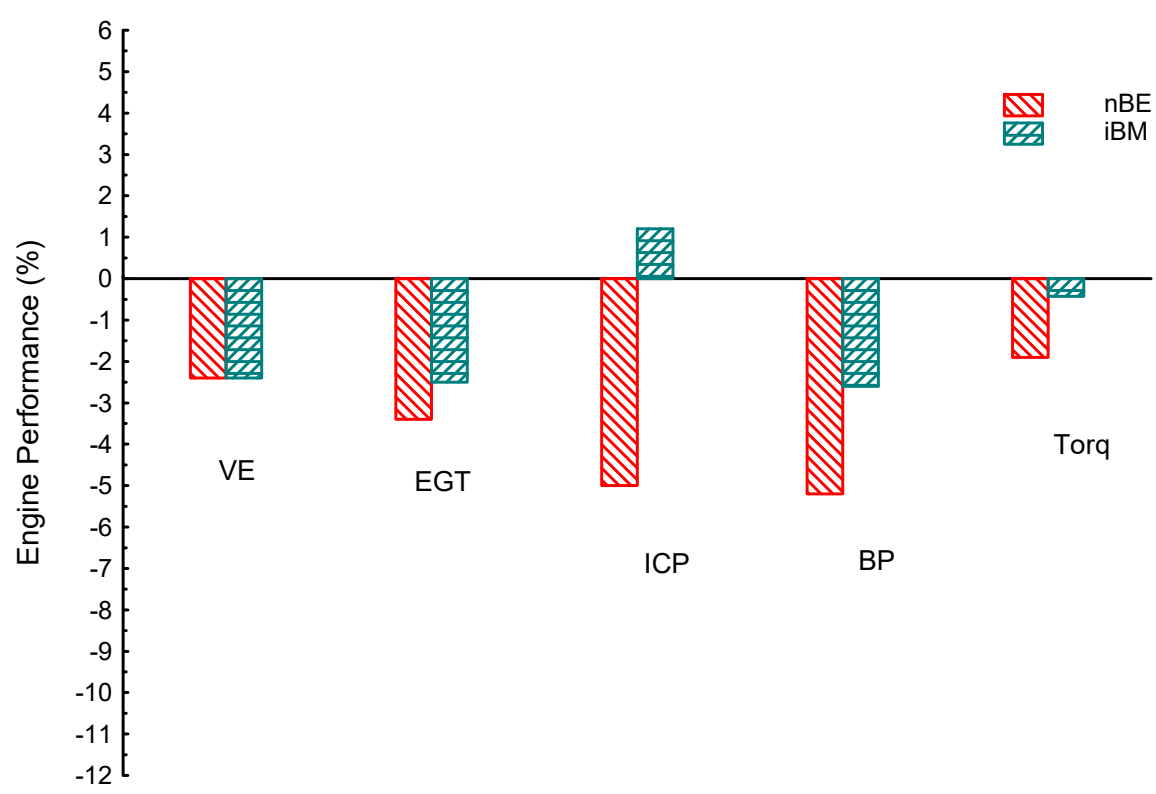

Figure 5. Comparison of volumetric efficiency (VE), exhaust gas temperature (EGT), in-cylinder pressure (ICP), brake power (BP), and torque (Torq) for i-butanol-bio-methanol-gasoline blends (iBM), n-butanol-bio-ethanol-gasoline blends (nBE) and neat gasoline (baseline) on average basis.

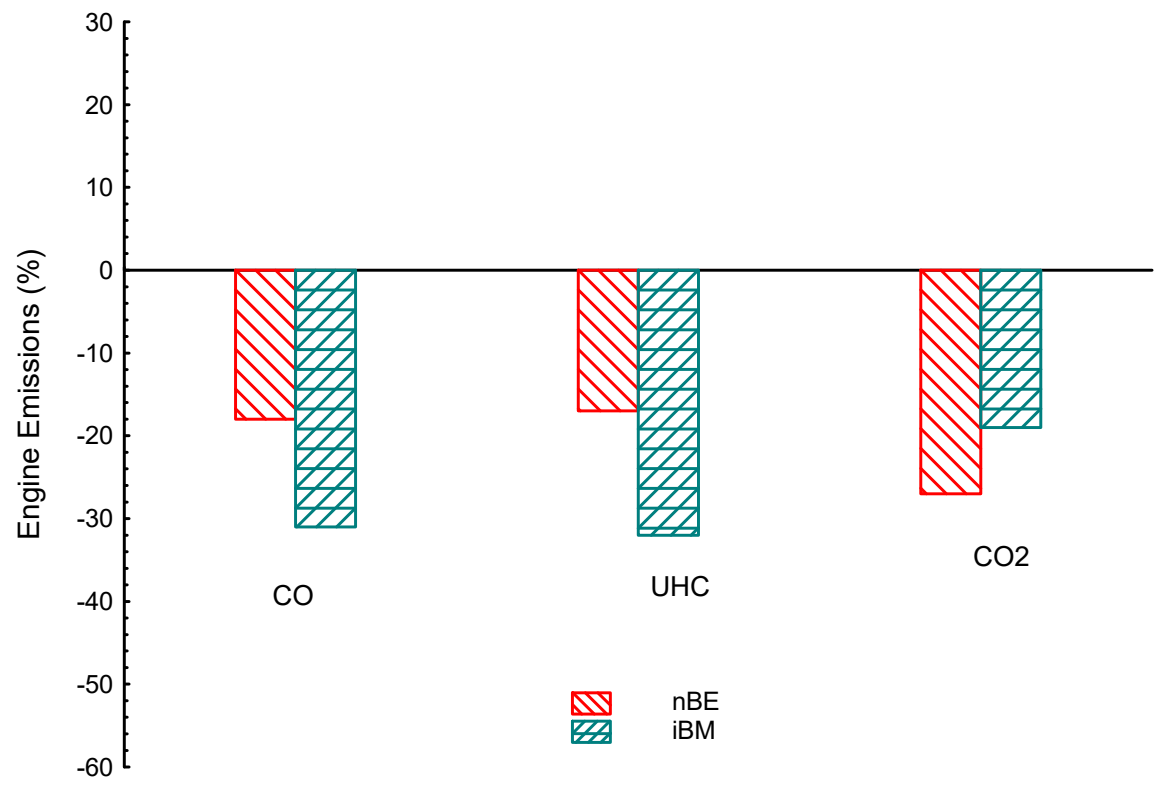

Figure 6. Comparison of $\mathrm{CO}, \mathrm{UHC}$ and $\mathrm{CO}_{2}$ emissions for i-butanol-bio-methanol-gasoline blends (iBM), n-butanol-bio-ethanol-gasoline blends (nBE) and neat gasoline (baseline) on average basis.

\section{Comparison between Single and Dual Biofuel Blends in SIE}

In a few publications, single and dual biofuels blended with gasoline were compared. A comparison between ethanol-methanol-gasoline blends (EM), bio-ethanol-gasoline blends (E) and methanol-gasoline blends (M) was carried out by Elfasakhany [153] on engine performance and emissions at similar rates of biofuel and engine working conditions, as shown in Figures 7 and 8. For the dual biofuel blends (EM), the results showed greater volumetric efficiency and output torque than ethanol-gasoline blends, and greater output brake power than that of methanol-gasoline blends. The author concluded that emissions (CO and $\mathrm{UHC}$ ) and performance were improved by both dual and single biofuel blends compared to pure gasoline. In another study, Elfasakhany et al. [154] investigated 
pollutant emissions and engine efficiency using n-butanol-methanol-gasoline blends; as shown in the figures, the findings were contrasted with single n-butanol-gasoline blends and neat gasoline (from Figures 9 and 10). In the case of a high rate of biofuel blended into gasoline, the authors suggested dual biofuel blends, but single biofuel blends were needed at a low rate. Balaji et al. [155] investigated ethanol-i-butanol-gasoline mixtures' outputs and exhaust emissions in SIE at constant engine speeds, but under different conditions of engine torque. The study contrasted dual biofuel blends (10\% ethanol-2.5\% i-butanol, $10 \%$ ethanol-5\% i-butanol and 10\% ethanol-7.5\% i-butanol in gasoline) with single blends $(10,20$ and $30 \%$ ethanol in gasoline), but there was no distinction between dual biofuel blends and i-butanol-gasoline blends in the study. The findings showed a decrease in $\mathrm{CO}$ and $\mathrm{HC}$ emissions and an increase in NOx emissions (dual and single) relative to pure gasoline for both fuel blends. The outcome also resulted in the growth of volumetric efficiency, braking power, thermal efficiency, and fuel consumption in dual and single blends relative to pure gasoline. Siwale et al. [156] compared dual biofuel blend efficiency, combustion and emission characteristics (53\% methanol-17\% n-butanol-30\% gasoline) and a couple of single biofuel blends (70\% methanol-30\% gasoline and $20 \%$ methanol- $80 \%$ gasoline). The study advocated the use of dual blends over single blends or pure gasoline. Nazzal [157] researched engine performance using dual biofuel blends of $6 \%$ ethanol-6\% methanol-88\% gasoline and a few single biofuel blends $(12 \%$ methanol in gasoline and $12 \%$ ethanol in gasoline). In contrast to pure gasoline fuel, engine performance (thermal efficiency and brake power) showed an improvement in all fuel blends. In contrast with pure gasoline, it is also shown that brake-specific fuel consumption has been improved for all fuel blends. A comparison of engine efficiency and emissions using $\mathrm{n}$-butanol-ibutanol-gasoline (niB) blends and i-butanol-gasoline blends (iB) and pure gasoline at two extreme engine speeds ( 2600 and $3400 \mathrm{r} / \mathrm{min}$ ) was undertaken by Elfasakhany [158], as shown in Figures 11 and 12. The findings showed that the n-butanol-i-butanol-gasoline blends increased pollutant emissions more significantly than i-butanol-gasoline blends; in addition, the dual biofuel blends (niB) increased exhaust gas emissions by 15, 20 and 34\% for $\mathrm{UHC}, \mathrm{CO}$ and $\mathrm{CO}_{2}$, respectively, compared to clean gasoline. The findings also showed that n-butanol-i-butanol-gasoline blends enhanced engine efficiency compared to single biofuel blends (iB), but that depends on the speed of the engine. As seen from Figure 11, the engine output using $\mathrm{niB}$ at both test speeds is better than that of $\mathrm{iB}$ (with the exception of torque at $2600 \mathrm{r} / \mathrm{min}$, volumetric efficiency at $3400 \mathrm{r} / \mathrm{min}$ and EGT). In summary, positive n-butanol/i-butanol additions to gasoline fuel include engine efficiency reporting and emission reductions compared to i-butanol-gasoline under the same engine operating conditions, depending on engine speeds. In the end, the author favored the dual blends of biofuel as opposed to the single one and/or pure gasoline. Elfasakhany [159] also analyzed blends of ethanol-i-butanol-gasoline, and contrasted the findings with the gasoline and i-butanol-gasoline, as shown in Figures 13 and 14; the study explored the potential for the use of dual blends as a fossil fuel substitute for the next decade. The results have shown that ethanol-i-butanol-gasoline blends have increased emissions of contaminants and engine efficiency relative to i-butanol-gasoline blends. In addition, dual biofuel blends increased the emissions of contaminants by respectively 15, 34 and 20\% for $\mathrm{UHC}_{2} \mathrm{CO}_{2}$ and $\mathrm{CO}$ emissions relative to those of renewable gasoline. The author concluded that the dual biofuel blends may possibly offer the upcoming generation a fossil fuel alternative for gasoline engines; the author supported his conclusion by proving the many benefits of dual biofuel blends over single biofuel blends, as well as neat gasoline. The complete comparisons are summarized in Table 2 for engine performance and emissions of single and dual blended alcohols. 


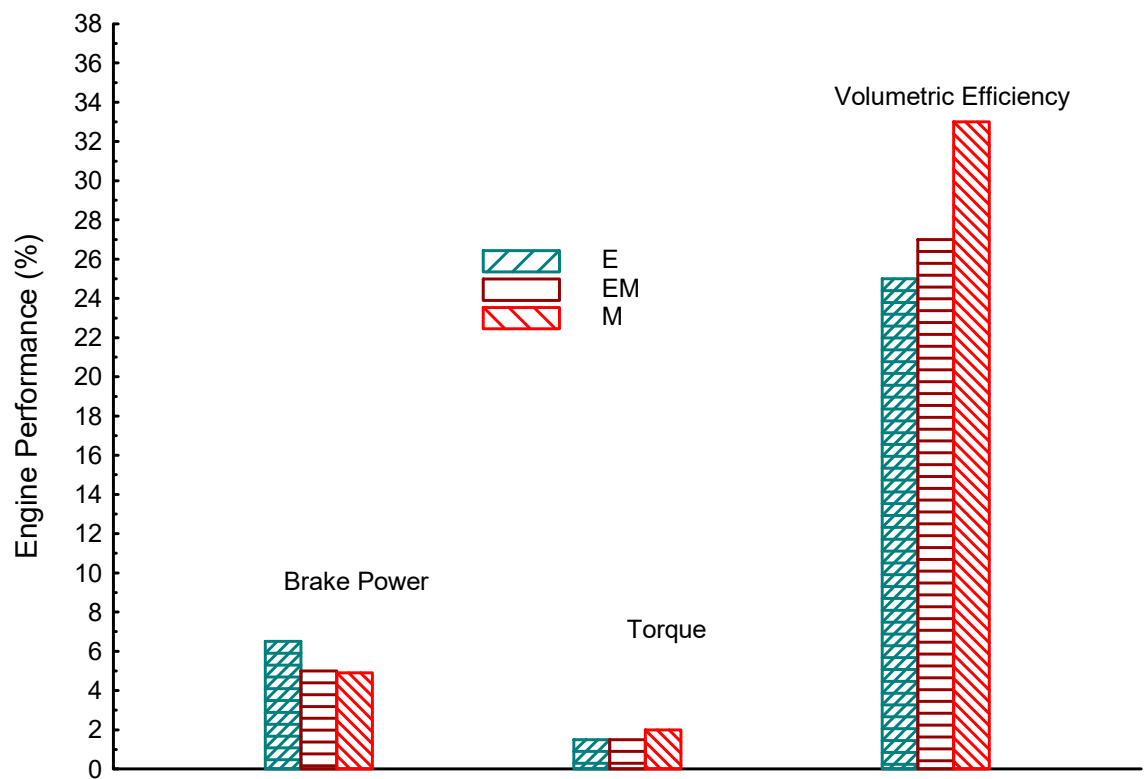

Figure 7. Comparisons of brake power, volumetric efficiency and torque for ethanol-methanol (EM), ethanol (E) and methanol (M) blended with gasoline and neat gasoline (baseline) in \%.

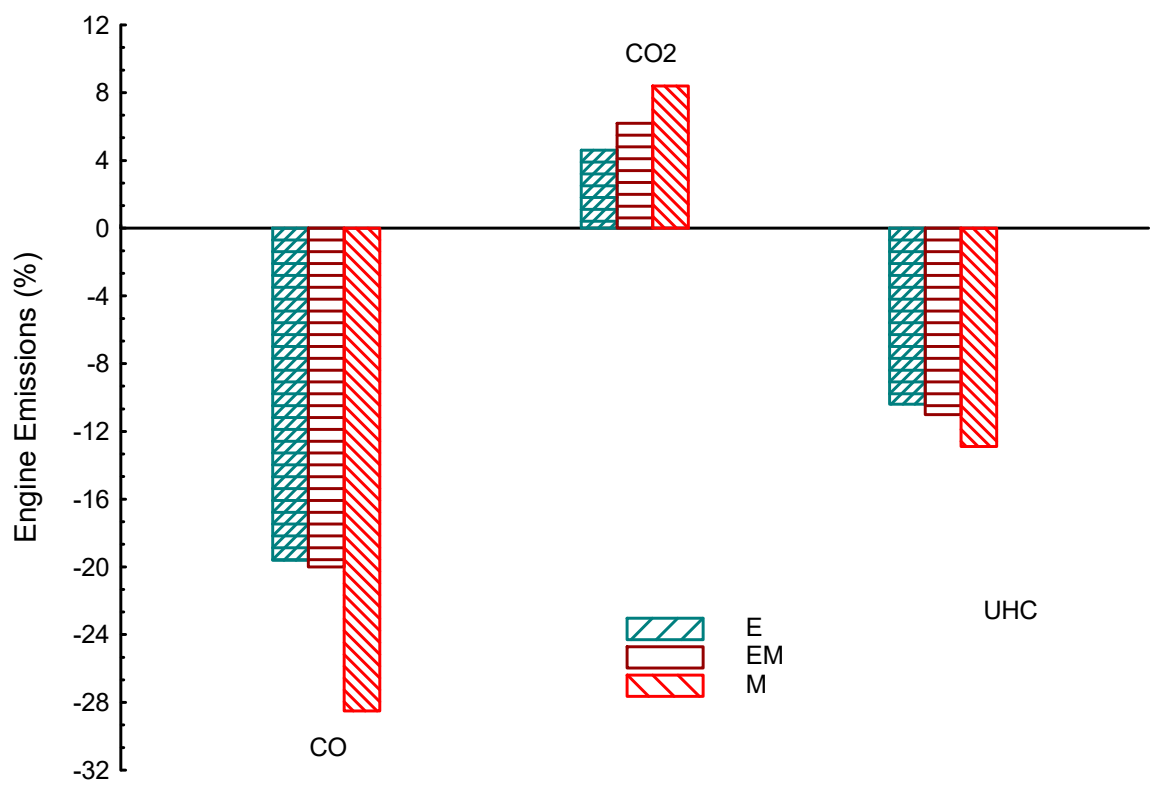

Figure 8. Comparisons of $\mathrm{CO}, \mathrm{CO}_{2}$ and UHC emissions for ethanol-methanol (EM), ethanol (E) and methanol (M) blended with gasoline and neat gasoline (baseline) in \%. 


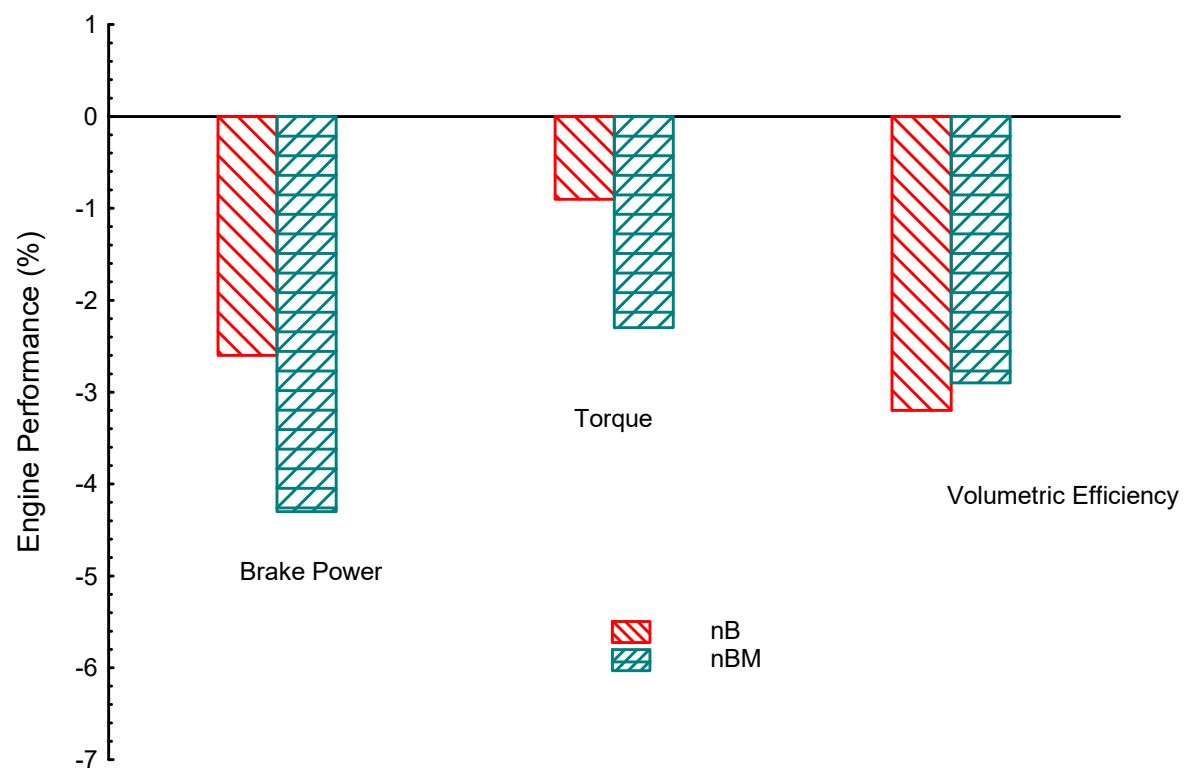

T

Figure 9. Comparisons of brake power, volumetric efficiency and torque for n-butanol-methanol (nBM) and n-butanol (nB) blended with gasoline and neat gasoline (baseline) in \%.

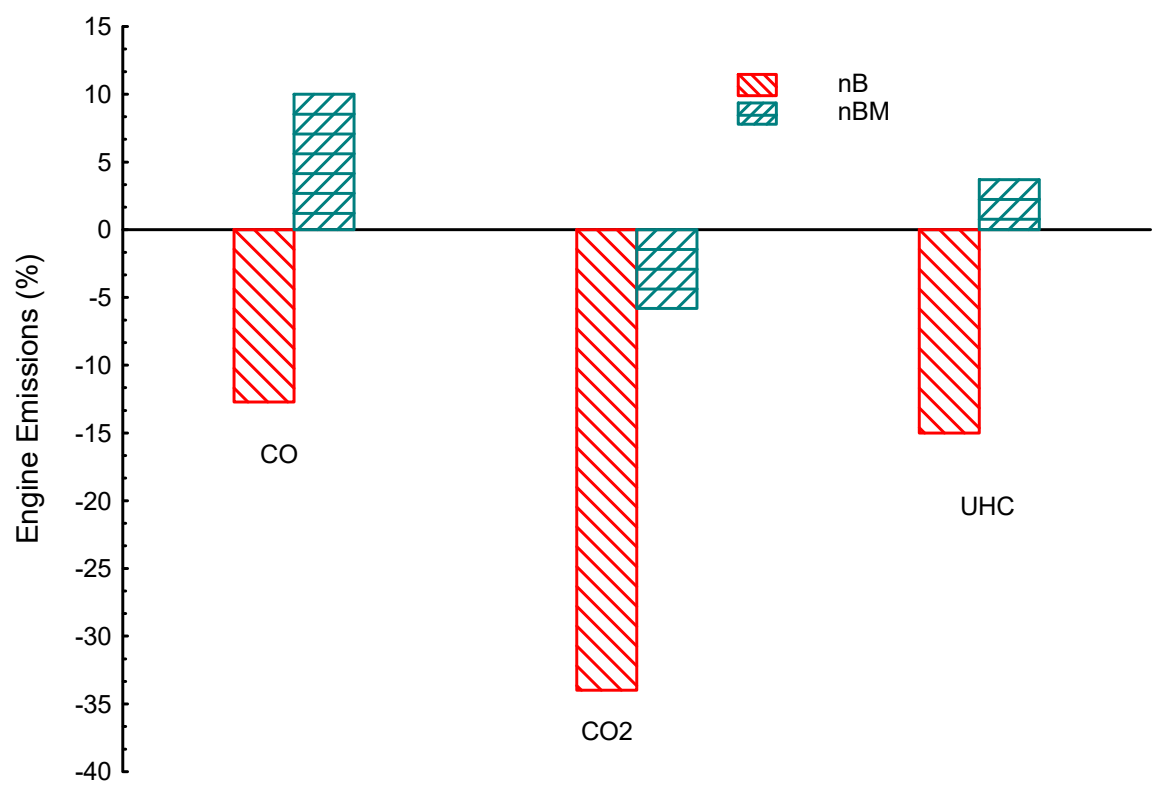

Figure 10. Comparisons of $\mathrm{CO}, \mathrm{CO}_{2}$ and UHC emissions for n-butanol-methanol (nBM) and nbutanol (nB) blended with gasoline and neat gasoline (baseline) in \%. 


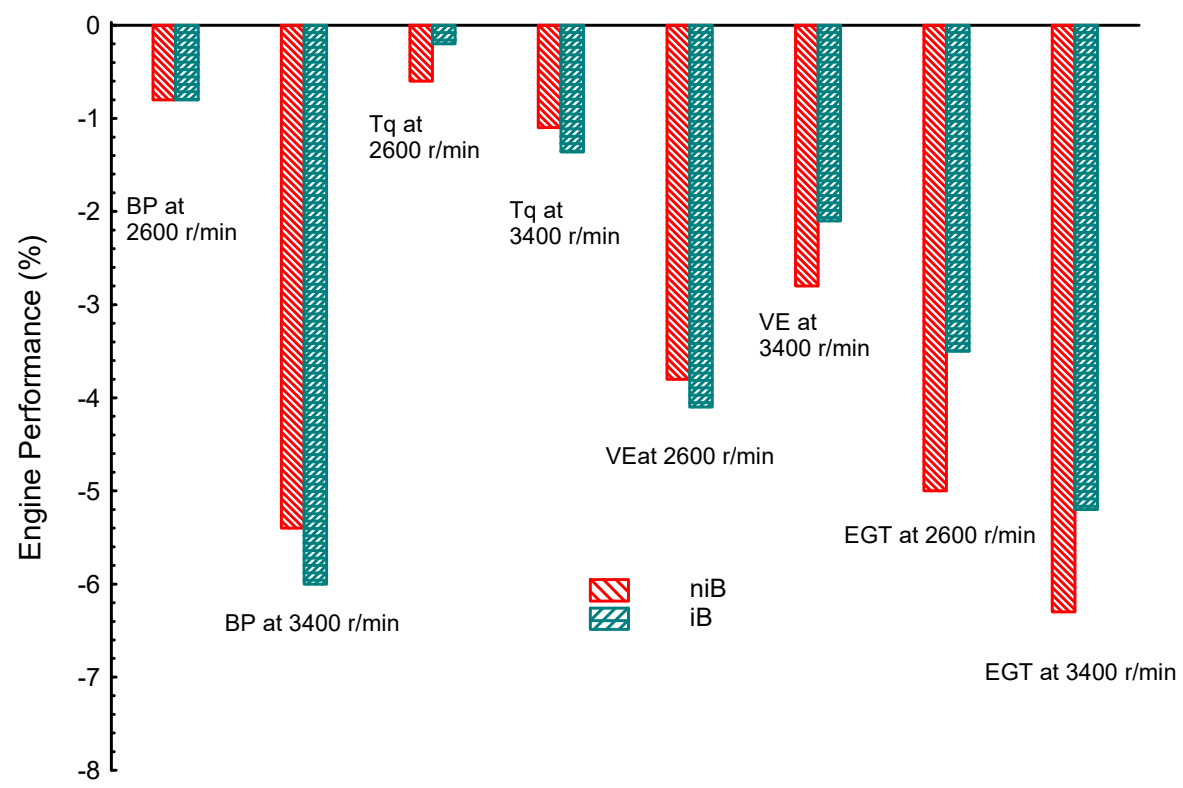

Figure 11. Comparison of brake power (BP), torque (Tq), volumetric efficiency (VE) and exhaust gas temperature (EGT) for i-butanol-gasoline blends (iB), n-butanol-i-butanol-gasoline blends (niB) and neat gasoline (baseline) at two different concentrations.

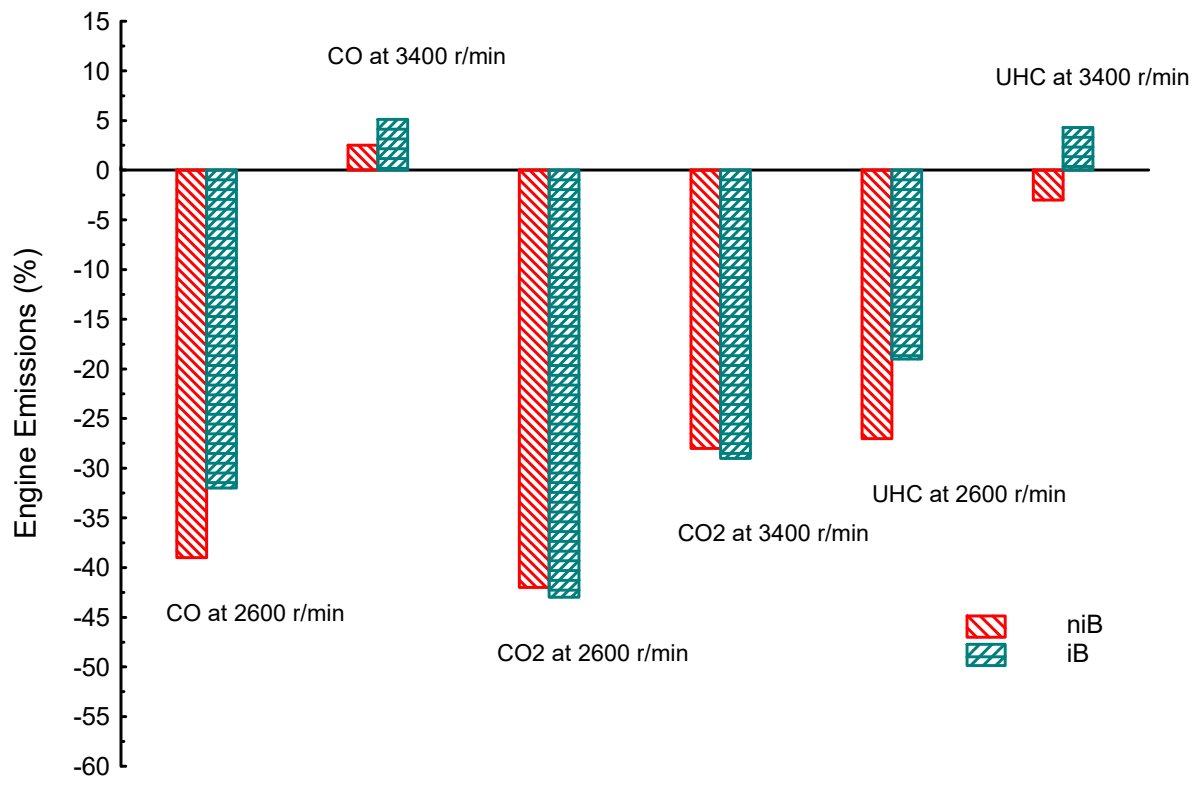

Figure 12. Comparison of $\mathrm{CO}, \mathrm{CO}_{2}$ and UHC emissions for i-butanol-gasoline blends (iB), n-butanoli-butanol-gasoline blends (niB) and neat gasoline (baseline) at two different speeds. 


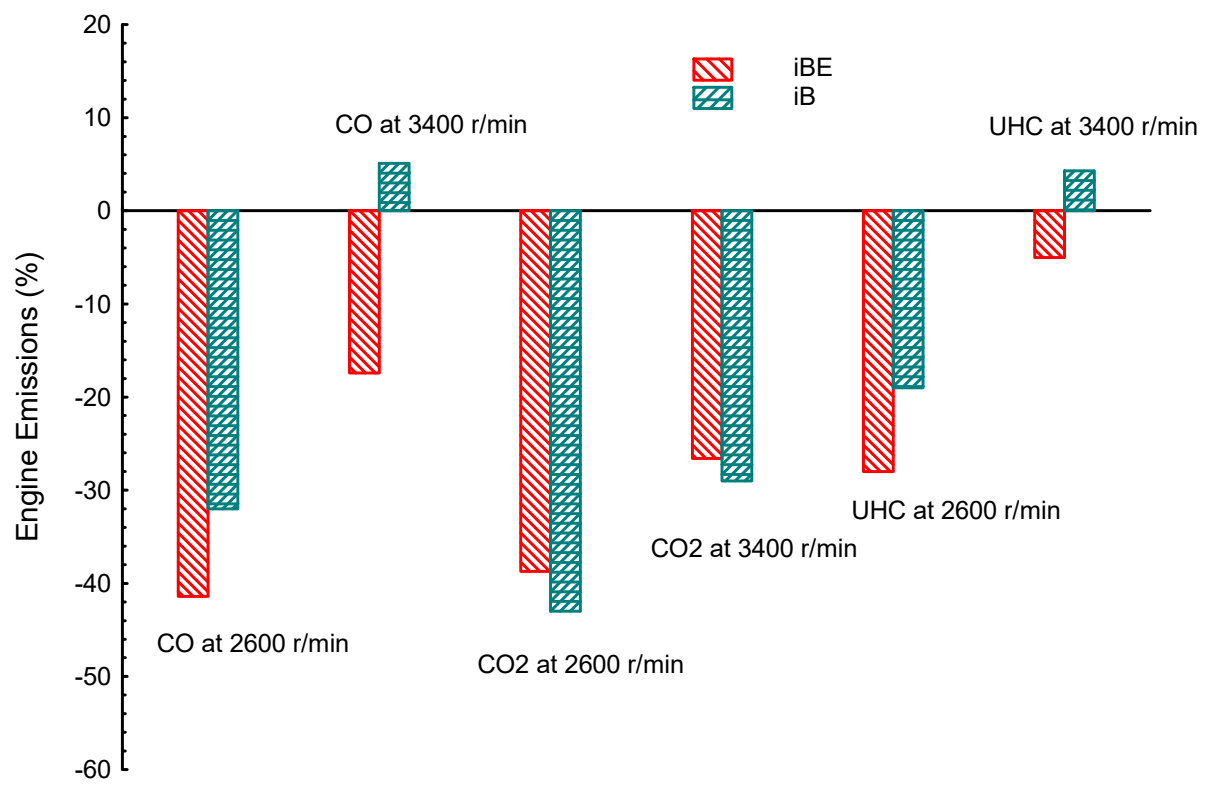

Figure 13. Comparison of $\mathrm{CO}, \mathrm{CO}_{2}$ and $\mathrm{UHC}$ emissions for i-butanol-bio-ethanol-gasoline blends (iBE), i-butanol-gasoline blends (iB) and neat gasoline (baseline) at two different speeds (2600 and $3400 \mathrm{r} / \mathrm{min}$ ).

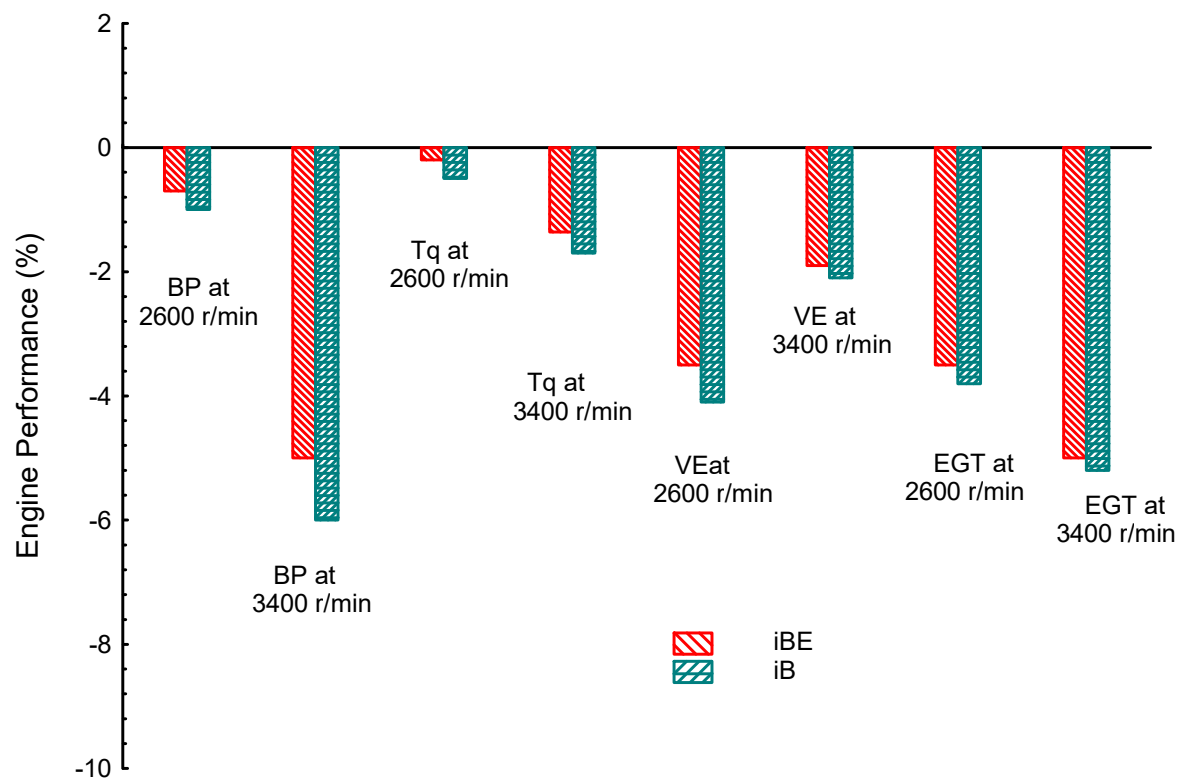

Figure 14. Comparison of brake power (BP), torque (Tq), volumetric efficiency (VE) and exhaust gas temperature (EGT) for i-butanol-bio-ethanol-gasoline blends (iBE), i-butanol-gasoline blends (iB) and neat gasoline (baseline) at two different speeds (2600 and $3400 \mathrm{r} / \mathrm{min}$ ). 
Table 2. Performance and emissions of single and dual alcohol blends.

\begin{tabular}{|c|c|c|c|c|c|c|}
\hline Biofuel & BP & $\mathrm{Tq}$ & VE & $\mathrm{CO}$ & UHC & $\mathrm{CO}_{2}$ \\
\hline E & 8.5 & 1.2 & 16 & -20 & -10 & 4.6 \\
\hline $\mathrm{AC}$ & 3.3 & 1.6 & 1.2 & -32 & -20 & -24.6 \\
\hline iB & -5.6 & -1.36 & -2.1 & -11.6 & -6.8 & -36 \\
\hline $\mathrm{nB}$ & -3.6 & -1.6 & -2.6 & -10 & -16.2 & -35 \\
\hline $\mathrm{M}$ & 1 & 0.5 & 21 & -30 & -12.8 & 10 \\
\hline $\mathrm{iBE}$ & -2.3 & -1.7 & -2.7 & -14 & -14 & -14 \\
\hline niB & -3.1 & -1.9 & -3.3 & -5 & -13.5 & -18 \\
\hline EM & 5 & 1.5 & 17 & -21 & -18 & 6.3 \\
\hline $\mathrm{nBM}$ & -4.3 & -2.3 & -2.9 & 10 & 3.7 & -5.8 \\
\hline $\mathrm{iBM}$ & -2.6 & -0.43 & -2.4 & -31 & -32 & -19 \\
\hline $\mathrm{nBE}$ & -5.2 & -1.9 & -2.4 & -18 & -17 & -27 \\
\hline
\end{tabular}

\section{Benefits and Weaknesses of Using Biofuels in SIE}

Biofuels show many benefits, such as decreasing greenhouse gases (GHG) and global warming, and shortening the dependency on fossil fuels. In the literature, some studies have discussed the advantages of specific biofuels in terms of combustion and emissions. In particular, Ryojiro Minato [160] discussed the advantages of bio-ethanol; Liu et al. [161] discussed the advantages of bio-methanol; Veza et al. [162] discussed the advantages of butanol. In other studies, researchers discussed the disadvantages of biofuels [163]. One study summarized the advantages and disadvantages of different biofuel types. The benefits and weaknesses of using biofuels in SIE either in single or dual blended conditions with gasoline are summarized by Elfasakhany [164]. The study concluded that the biofuels can offer promising well-to-wheel $\mathrm{CO} 2$ balance in our environment, and increase engine efficiency and output power. Biofuels' oxygen content also offers benefits for the fuel combustion. Nevertheless, biofuels showed some weaknesses, such as minor carbon and hydrogen contents and heating values, and some corrosiveness of engine systems for some biofuel type(s). Boiling temperature, absorption with water, vapor toxicity and autoignition of biofuels showed benefits for some types and weaknesses for others; a summary of the benefits and weaknesses of using biofuels in cars is given in Table 3.

Table 3. Benefits and weaknesses of using biofuels compared to gasoline in SI engines.

\begin{tabular}{llllll}
\hline Properties & Bio-Ethanol & Bio-Methanol & I-Butanol & N-Butanol & Acetone \\
\hline Performance & Ben. & Ben. & Ben. & Ben. & Ben. \\
Emissions & Ben. & Ben. & Ben. & Ben. & Ben. \\
Oxygen content & Ben. & Ben. & Ben. & Ben. & Ben. \\
Hydrogen content & Wek. & Wek. & Wek. & Wek. & Wek. \\
Carbon content & Wek. & Wek. & Wek. & Wek. & Wek. \\
Absorption with water & Wek. & Wek. & Ben. & Ben. & Ben. \\
Boiling Temp. & Wek. & Wek. & Ben. & Ben. & Wek. \\
Vapor toxicity & Ben. & Ben. & Wek. & Wek. & Ben. \\
Heating value & Wek. & Wek. & Wek. & Wek. & Wek. \\
Autoignition & Ben. & Ben. & Wek. & Wek. & Ben. \\
Corrosion & Wek. & Wek. & Ben. & Ben. & Wek. \\
\hline
\end{tabular}

Ben: benefits, Wek: weaknesses.

\section{Future Biofuels for SIE}

The future fuel for SIE is gasoline, which will most probably be kept for the coming decade(s) [165]. This is because of its cost effectiveness and high heating value. The biofuels would be used as blended fuels with gasoline. The most promising biofuels are the second and third generations. The fourth generation biofuels are still under development and not fully dependable [37]. The first generation biofuels are no longer applied due to their food-dependency for production. Biofuels from second and third generations can reduce 
the greenhouse gas life cycle. Among the promising second and third generation biofuels, bio-methanol, bio-ethanol, butanol, and bio-acetone are within the foreground.

The next-generation biofuels for SI engines are thought to be the dual biofuel blends. This conclusion is drawn from the early publications, as discussed earlier. Additionally, the conclusion of recommending dual biofuel blends as next-generation fuels is also motivated by the benefits and weaknesses of biofuels. In detail, many benefits are found for ethanol and methanol, but due to some drawbacks, as discussed earlier, researchers have moved towards new biofuel generations, which are n-butanol and i-butanol. However, the new generation showed also some drawbacks. Accordingly, researchers tried to investigate the benefits and weaknesses of different biofuels by mixing them together. For example, most of the issues with ethanol are advantages in i-butanol biofuels, and vice versa; difficulties in using bioethanol-gasoline blend fuels are regulated by the introduction of i-butanol to those blends, and there are similar approaches for i-butanol-gasoline blends, e.g., by the introduction of bio-ethanol. This method is believed to work because i-butanol has been used as a co-solvent to restore the stability of the ethanol-gasoline blend cycle [166].

\section{A Proposed Method to Reduce Engine Pollutant Emissions}

There are different methods or techniques proposed in the literature to reduce emissions from CIE [167-169]; however, these are rarely in the SIE. A proposed method to reduce engine pollutant emissions was introduced by Elfasakhany $[170,171]$. The method is based on reformulating the engine pollutant emissions into new fuels, and then re-using this new fuel in the engine again. The author applied exothermic partial oxidation using metal oxides of $\mathrm{MgO}, \mathrm{ZnO}$ and /or $\mathrm{Fe}_{2} \mathrm{O}_{3}$ to instantaneously produce syngas from $\mathrm{HC}$ emissions. Such neutral thermo-reactions have the opportunity of creating syngas in autothermal and noncatalytic reactors, with significant avoidance of creating $\mathrm{CO}_{2}$ emission. The $\mathrm{CO}$ emission stream can be treated using a water-gas shift reaction. Regarding $\mathrm{CO}_{2}$ emission, the author used different oxide materials as sorbents for the $\mathrm{CO}_{2}$, such as lithium zirconates, calcium oxide, lithium silicates and hydrotalcite (HTs)-like materials; the author recommends himself the use of hydrotalcite (HTs)-like materials as an attractive option for $\mathrm{CO}_{2}$ sorption because, of their high sorption capacity at a low temperature.

\section{Conclusions}

The state of the art of using biofuels in spark ignition engines is reviewed and discussed. Different biofuels, include ethanol, methanol, n-butanol, i-butanol, and acetone, are covered in the study, and compared with each other and with the commercial gasoline under the same rates and conditions. Ethanol and methanol showed many benefits and some drawbacks as alternative fuels for spark ignition engines, in comparison with gasoline. They have the ability to improve engine performance and pollutant emissions; however, they showed some problems in terms of engine starting condition in cold environments as well as a vapor lock in hot climate conditions. They showed also incompatibility with some engine material, and their miscibility with water is another disadvantage. On the other hand, i-butanol and n-butanol showed advantages in engine starting and vapor lock problems. However, they showed very low engine performance and great emissions (CO and UHC). They offer advantages for the greenhouse effect, e.g., low $\mathrm{CO}_{2}$ emissions are produced from butanol. The ethanol and methanol biofuel blends introduced the highest $\mathrm{CO}_{2}$ emissions. Regarding acetone blended fuel, it showed a moderate high performance and the lowest emissions (UHC and $\mathrm{CO}$ ). The $\mathrm{CO}_{2}$ values for different blends are 10, 4.6, $-24.6,-35$, and $-36 \%$ for $\mathrm{M}, \mathrm{E}, \mathrm{AC}, \mathrm{nB}$, and $\mathrm{iB}$, respectively. The $\mathrm{CO}$ and $\mathrm{UHC}$ for $\mathrm{AC}$ are -32 and $-20 \%$, respectively, which are the lowest, while the greatest are achieved by $\mathrm{iB}(-11.6$ and $-6.8 \%$ for $\mathrm{CO}$ and $\mathrm{UHC}$, respectively). Other single blends introduced values in between. The greatest performance was introduced by AC for torque (1.6\%), E for brake power $(8.5 \%)$, and $\mathrm{M}$ for volumetric efficiency (21\%). Blends of dual ethanol and methanol biofuel blends with gasoline showed the best performance and emissions among other dual biofuel blends (n-butanol-i-butanol, i-butanol-ethanol, i-butanol-methanol, 
n-butanol-ethanol). However, n-butanol-i-butanol blended with gasoline demonstrated the highest emissions and the lowest performance among other dual biofuel blends. Based on the benefits and drawbacks of different biofuels, dual biofuel blends are thought to be the next generation of fuels for SIE. Finally, one may reduce engine pollutant emissions and reformulate the emissions into new fuels by using metal oxides to produce simultaneously syngas from $\mathrm{CO}, \mathrm{CO}_{2}$ and $\mathrm{UHC}$ emissions.

Funding: This work was funded by Taif University researchers supporting project number (TURSP2020/40), Taif University, Taif, Saudi Arabia.

Acknowledgments: This work was supported by Taif University researchers supporting project number (TURSP-2020/40), Taif University, Taif, Saudi Arabia.

Conflicts of Interest: The author declares no conflict of interest.

\section{References}

1. Midttun, A.; Piccini, P.B. Facing the climate and digital challenge: European energy industry from boom to crisis and transformation. Energy Policy 2017, 108, 330-343. [CrossRef]

2. Celik, A.N.; Ozgür, E. Review of Turkey's photovoltaic energy status: Legal structure, existing installed power and comparative analysis. Renew. Sustain. Energy Rev. 2020, 134, 110344. [CrossRef]

3. Elfasakhany, A.; Bai, X.S. Numerical and experimental studies of irregular-shape biomass particle motions in turbulent flows. Eng. Sci. Technol. 2019, 22, 249-265. [CrossRef]

4. Alpanda, S.; Alva, A.P. Oil crisis, energy-saving technological change and the stock market crash of 1973-74. Rev. Econ. Dyn. 2010, 13, 824-842.

5. Ajanovic, A.; Haas, R. On the future prospects and limits of biofuels in Brazil, the US and EU. Appl. Energy 2014, 135, 730-737. [CrossRef]

6. Thompson, W.; Whistance, J.; Meyer, S. Effects of US biofuel policies on US and world petroleum product markets with consequences for greenhouse gas emissions. Energy Policy 2011, 39, 5509-5518. [CrossRef]

7. Kay, A.; Ackrill, R. Governing the transition to a biofuels economy in the US and EU: Accommodating value conflicts, implementing uncertainty. Policy Soc. 2012, 31, 295-306. [CrossRef]

8. Martinez, C.L.M.; Saari, J.; Melo, Y.; Cardoso, M.; Almeida, G.M.; Vakkilainen, E. Evaluation of thermochemical routes for the valorization of solid coffee residues to produce biofuels: A Brazilian case. Renew. Sustain. Energy Rev. 2021, 137. [CrossRef]

9. Usmani, R.A. Potential for energy and biofuel from biomass in India. Renew. Energy 2020, 155, 921-930. [CrossRef]

10. Sindelar, S.; Aradhey, A. India Biofuels Annual 2017. In USDA Foreign Agriculture Service; New Delhi, India, 2017. Available online: https: / / www.fas.usda.gov/data/india-biofuels-annual-1 (accessed on 25 November 2020).

11. Buchspies, B.; Kaltschmitt, M.; Neuling, U. Potential changes in GHG emissions arising from the introduction of biorefineries combining biofuel and electrofuel production within the European Union-A location specific assessment. Renew. Sustain. Energy Rev. 2020, 134, 0395. [CrossRef]

12. Bórawski, P.; Borawska, A.B.; Szymanska, E.J.; Jankowski, K.J.; Dubis, B.; Dunn, J.W. Development of renewable energy sources market and biofuels in The European Union. J. Clean. Prod. 2019, 228, 467-484. [CrossRef]

13. Hao, H.; Liu, Z.; Zhao, F.; Ren, J.; Chang, S.; Rong, K.; Du, J. Biofuel for vehicle use in China: Current status, future potential and policy implications. Renew. Sustain. Energy Rev. 2018, 82, 645-653. [CrossRef]

14. Ge, J.C.; Kim, H.Y.; Yoon, S.K.; Choi, N.J. Optimization of palm oil biodiesel blends and engine operating parameters to improve performance and PM morphology in a common rail direct injection diesel engine. Fuel 2020, 260, 6326. [CrossRef]

15. Ge, J.C.; Kim, H.Y.; Yoon, S.K.; Choi, N.J. Reducing volatile organic compound emissions from diesel engines using canola oil biodiesel fuel and blends. Fuel 2018, 218, 266-274. [CrossRef]

16. Elfasakhany, A. Powder biomass fast pyrolysis as in combustion conditions: Numerical prediction and validation. Renew. Energy Focus 2018, 27, 78-87. [CrossRef]

17. Elfasakhany, A. Modeling of Pulverised Wood Flames. Ph.D. Thesis, Fluid Mechanics Department, Lund University, Lund, Sweden, 2005.

18. Elfasakhany, A.; Bai, X.S. Modeling of Pulverised Wood Combustion: A Comparison of Different Models. Prog. Comp. Fluid Dyn. 2006, 6, 188-199. [CrossRef]

19. Elfasakhany, A.; Klason, T.; Bai, X.S. Modeling of Pulverised Wood Combustion Using a Functional Group Model. Combust. Theory Modeling 2008, 12, 883-904. [CrossRef]

20. Elfasakhany, A. Modeling of Secondary Reactions of Tar (SRT) Using a Functional Group Model. Int. J. Mech. Eng. Tech. 2012, 3, 123-136.

21. Sangeeta; Moka, S.; Pande, M.; Rani, M.; Gakhar, R.; Sharma, M.; Rani, J.; Bhaskarwar, A.N. Alternative fuels: An overview of current trends and scope for future. Renew. Sustain. Energy Rev. 2014, 32, 697-712. [CrossRef]

22. Thangavelu, S.K.; Ahmedb, A.S.; Ani, F.N. Review on bioethanol as alternative fuel for spark ignition engines. Renew. Sustain. Energy Rev. 2016, 56, 820-835. [CrossRef] 
23. Elfasakhany, A. Alcohols as Fuels in Spark Ignition Engines: Second Blended Generation; Lambert Academic Publishing: Bahnhofstrabe, Germany, 2017; ISBN 978-3-659-97691-9.

24. Elfasakhany, A. Benefits and Drawbacks on the Use Biofuels in Spark Ignition Engines; Lambert Academic Publishing: Beau Bassin, Mauritius, 2017; ISBN 978-620-2-05720-2.

25. Elfasakhany, A.; Tao, L.X.; Bai, X.S. Transport of pulverized wood particles in turbulent flow: Numerical and experimental studies. Energy Procedia 2014, 61, 1540-1543. [CrossRef]

26. Elfasakhany, A.; Tao, L.; Espenas, B.; Larfeldt, J.; Bai, X.S. Pulverised Wood Combustion in a Vertical Furnace: Experimental and Computational Analyses. Appl. Energy 2013, 112, 454-464. [CrossRef]

27. Lin, C.Y.; Lu, C. Development perspectives of promising lignocellulose feedstocks for production of advanced generation biofuels: A review. Renew. Sustain. Energy Rev. 2021, 136, 0445. [CrossRef]

28. McDowall, W.; Eames, M. Forecasts, scenarios, visions, backcasts and roadmaps to the hydrogen economy: A review of the hydrogen futures literature. Energy Pol. 2006, 34, 1236-1250. [CrossRef]

29. Mahmudul, H.M.; Hagos, F.Y.; Mamat, R.; Adam, A.A.; Ishak, W.F.W.; Alenezi, R. Production, characterization and performance of biodiesel as an alternative fuel in diesel engines-a review. Renew. Sustain. Energy Rev. 2017, 72, 497-509. [CrossRef]

30. Balat, M.; Balat, H. Recent trends in global production and utilization of bio-ethanol fuel. Appl. Energy 2009, 86, $2273-2282$. [CrossRef]

31. Bezerra, T.L.; Ragauskas, A.J. A review of sugarcane bagasse for second-generation bioethanol and biopower production. Biofuel. Bioprod. Biorefin. 2016, 10, 634-647. [CrossRef]

32. Gupta, A.; Verma, J.P. Sustainable bio-ethanol production from agro-residues: A review. Renew. Sustain. Energy Rev. 2015, 41, 550-567. [CrossRef]

33. Hall, L.M.H.; Buckley, A.R. A review of energy systems models in the UK: Prevalent usage and categorisation. Appl. Energy 2016, $169,607-628$.

34. Mofijur, M.; Masjuki, H.H.; Kalam, M.; Rahman, S.A.; Mahmudul, H. Energy scenario and biofuel policies and targets in ASEAN countries. Renew. Sustain. Energy Rev. 2015, 46, 51-61. [CrossRef]

35. Azad, A.K.; Rasul, M.; Khan, M.M.K.; Sharma, S.C.; Hazrat, M. Prospect of biofuels as an alternative transport fuel in Australia. Renew. Sustain. Energy Rev. 2015, 43, 331-351. [CrossRef]

36. Cremonez, P.A.; Feroldi, M.; Araújo, A.V.; Borges, M.N.; Meier, T.W.; Feiden, A.; Teleken, J.G. Biofuels in Brazilian aviation: Current scenario and prospects. Renew. Sustain. Energy Rev. 2015, 43, 1063-1072. [CrossRef]

37. Alizadeh, R.; Peter, D.; Soltanisehat, L.L. Outlook on biofuels in future studies: A systematic literature review. Renew. Sustain. Energy Rev. 2020, 134, 0326. [CrossRef]

38. Singh, R.S.; Walia, A. Biofuels Historical Perspectives and Public Opinions; CRC Press; Taylor and Francis Group: Boca Raton, FL, USA, 2016; ISBN 9781315370743.

39. Bergthorson, J.M.; Thomson, M.J. A review of the combustion and emissions properties of advanced transportation biofuels and their impact on existing and future engines. Renew. Sustain. Energy Rev. 2015, 42, 1393-1417. [CrossRef]

40. Nadaleti, W.C.; Przybyla, G.; Filho, P.B. Analysis of emissions and combustion of typical biofuels generated in the agroindustry sector of Rio Grande do Sul State-Brazil: Bio75, syngas and blends. J. Clean. Prod. 2019, 208, 988-998. [CrossRef]

41. Santos, I.T. Confronting governance challenges of the resource nexus through reflexivity: A cross-case comparison of biofuels policies in Germany and Brazil. Energy Res. Soc. Sci. 2020, 65, 1464.

42. Puricelli, S.; Cardellini, G.; Grosso, M. A review on biofuels for light-duty vehicles in Europe. Renew. Sustain. Energy Rev. 2021, 137, 0398. [CrossRef]

43. Liew, W.H.; Hassim, M.H.; Ng, D.K.S. Review of evolution, technology and sustainability assessments of biofuel production. J Clean. Prod. 2014, 71, 11-29. [CrossRef]

44. Carneiro, M.L.N.M.; Pradelle, F.; Braga, S.L.; Gomes, M.S.P.; Martins, A.R.F.A.; Turkovic, F. Potential of biofuels from algae: Comparison with fossil fuels, ethanol and biodiesel in Europe and Brazil through life cycle assessment (LCA). Renew. Sustain. Energy Rev. 2017, 73, 632-653. [CrossRef]

45. Alalwan, H.A.; Alminshid, A.H.; Aljaafari, H.A.S. Promising evolution of biofuel generations. Subject review. Renew. Energy Focus 2019, 28, 127-139. [CrossRef]

46. Oehlschlaeger, M.A.; Wang, H.; Sexton, M.N. Prospects for biofuels: A review. J. Therm. Sci. Eng. Appl. 2013, 5, 1006. [CrossRef]

47. Souza, L.L.P.; Lora, E.E.S.; Palacio, J.C.E.; Rocha, M.H.; Renó, M.L.G.; Venturini, O.J. Comparative environmental life cycle assessment of conventional vehicles with different fuel options, plug-in hybrid and electric vehicles for a sustainable transportation system in Brazil. J. Clean. Prod. 2018, 203, 444-468. [CrossRef]

48. Bhargavi, G.; Rao, N.P.; Renganathan, S. Review on the extraction methods of crude oil from all generation biofuels in last few decades. In IOP Conference Series: Materials Science and Engineering, Proceedings of the International Conference on Recent Advances in Materials, Mechanical and Civil Engineering, Hyderabad, India, 1-2 June 2017; IOP Publishing Ltd.: Bristol, UK, 2018; Volume 330. [CrossRef]

49. Awudu, I.; Zhang, J. Uncertainties and sustainability concepts in biofuel supply chain management: A review. Renew. Sustain. Energy Rev. 2012, 16, 1359-1368. [CrossRef]

50. Menten, F.; Chèze, B.; Patouillard, L.; Bouvart, F. A review of LCA greenhouse gas emissions results for advanced biofuels: The use of meta-regression analysis. Renew. Sustain. Energy Rev. 2013, 26, 108-134. [CrossRef] 
51. Gohain, M.; Khalifa, H.M.; Eldiehy, S.H.; Bardhan, P.; Laskar, K.; Phukon, H.; Mandal, M.; Kalita, D.; Deka, D. Bio-ethanol production: A route to sustainability of fuels using bio-based heterogeneous catalyst derived from waste. Process Saf. Environ. Prot. 2021, 146, 190-200. [CrossRef]

52. Neitzel, T.; Lima, C.S.; Biazi, L.E.; Collograi, K.C.; Costa, A.C.; Santos, L.V.; LutzIenczak, J. Impact of the Melle-Boinot process on the enhancement of second-generation ethanol production by Spathaspora passalidarum. Renew. Energy 2020, 160, 1206-1216. [CrossRef]

53. Abdollahipoor, B.; Shirazi, S.A.; Kenneth, F.; Bret, R.; Windom, C. Near-azeotropic volatility behavior of hydrous and anhydrous ethanol gasoline mixtures and impact on droplet evaporation dynamics. Fuel Process. Technol. 2018, 181, 166-174. [CrossRef]

54. Kumar, S.; Singh, N.; Prasad, R. Anhydrous ethanol: A renewable source of energy. Renew. Sustain. Energy Rev. 2010, 14, 1830-1844. [CrossRef]

55. Han, J.; Somers, L.M.T.; Cracknell, R.; Mohan, V.R.R. Experimental investigation of ethanol/diesel dual-fuel combustion in a heavy-duty diesel engine. Fuel 2020, 275, 7867. [CrossRef]

56. Polat, S. An experimental investigation on combustion, performance and ringing operation characteristics of a low compression ratio early direct injection HCCI engine with ethanol fuel blends. Fuel 2020, 277, 8092. [CrossRef]

57. Colorado, A.; McDonell, V. Surface stabilized combustion technology: An experimental evaluation of the extent of its fuel-flexibility and pollutant emissions using low and high calorific value fuels. Appl. Therm. Eng. 2018, 136, 206-218. [CrossRef]

58. Duc, K.N.; Tien, H.N.; Duy, V.N. Performance enhancement and emission reduction of used motorcycles using flexible fuel technology. J. Energy Inst. 2018, 91, 145-152. [CrossRef]

59. Elfasakhany, A. The effects of ethanol-gasoline blends on performance and exhaust emission characteristics of spark ignition engines. Int. J. Automot. Eng. 2014, 4, 608-620.

60. Garcia, G.; Arriola, E.; Chen, W.H.; De Luna, M.D. A comprehensive review of hydrogen production from methanol thermochemical conversion for sustainability. Energy 2021, 217, 119384. [CrossRef]

61. Mina, J.Z.; Restrepo, A.; Romero, C.; Quintero, H. Exergy analysis of a diesel engine converted to spark ignition operating with diesel, ethanol, and gasoline/ethanol blends. Sustain. Energy Technol. Assess. 2020, 42, 0803.

62. Sakthivel, P.; Subramanian, K.A.; Mathai, R. Experimental study on unregulated emission characteristics of a two-wheeler with ethanol-gasoline blends (E0 to E50). Fuel 2020, 262, 6504. [CrossRef]

63. Liu, H.; Wang, X.; Zhang, D.; Dong, F.; Liu, X.; Yang, Y.; Huang, H.; Wang, Y.; Wang, Q.; Zheng, Z. Investigation on Blending Effects of Gasoline Fuel with N-Butanol, DMF, and Ethanol on the Fuel Consumption and Harmful Emissions in a GDI Vehicle. Energies 2019, 12, 1845. [CrossRef]

64. Guo, T.; Duan, X.; Liu, Y.; Liu, J.; Zhou, X.; Li, Y.; Lai, M.C.; Guo, G. A comparative experimental study on emission characteristics of a turbocharged gasoline direct-injection (TGDI) engine fuelled with gasoline/ethanol blends under transient cold-start and steady-state conditions. Fuel 2020, 277, 8153. [CrossRef]

65. Iodice, P.; Senatore, A.; Langella, G.; Amoresano, A. Effect of ethanol-gasoline blends on CO and HC emissions in last generation SI engines within the cold-start transient: An experimental investigation. Appl. Energy 2016, 179, 182-190. [CrossRef]

66. Amine, M.; Ezis, N.; Barakat, A.Y. Volatility criteria of isomerate-enriched gasoline-ethanol blends. Egypt. J. Pet. 2020, 29, 227-233. [CrossRef]

67. Fan, Q.; Qi, Y.; Wang, Y.; Wang, Z. Investigation into pressure dependence of flame speed for fuels with low and high octane sensitivity through blending ethanol. Combust. Flame 2020, 212, 252-269. [CrossRef]

68. Roth, P.; Yang, J.; Peng, W.; Karavalakis, G. Intermediate and high ethanol blends reduce secondary organic aerosol formation from gasoline direct injection vehicles. Atmos. Environ. 2020, 220, 7064. [CrossRef]

69. Michael, J.W.; James, M.H.; Felix, H.B. Maize, sweet sorghum, and high biomass sorghum ethanol yield comparison on marginal soils in Midwest USA. Biomass Bioenergy 2017, 107, 164-171.

70. Cardona, E.; Rios, J.; Peña, J.; Peñuela, M.; Rios, L. King Grass: A very promising material for the production of second generation ethanol in tropical countries. Biomass Bioenergy 2016, 95, 206-213. [CrossRef]

71. Sun, Z.; Zhang, X.; Li, H.; Liu, T.; Sang, S.; Chen, S.; Duan, L.; Zeng, L.; Xiang, W.; Gong, J. Chemical looping oxidative steam reforming of methanol: A new pathway for auto-thermal conversion. Appl. Catal. B Environ. 2020, 269, 8758. [CrossRef]

72. Mansfield, A. A revised chemical kinetic mechanism for methanol combustion in sub and supercritical water. J. Supercrit. Fluids 2020, 166, 5023. [CrossRef]

73. Butera, G.; Fendt, S.; Jensen, S.H.; Lasse, A.J.; Clausen, R. Flexible methanol production units coupling solid oxide cells and thermochemical biomass conversion via different gasification technologies. Energy 2020, 208, 8432. [CrossRef]

74. Wu, Y.; Panigrahy, S.; Sahu, A.B.; Bariki, C.; Beeckmann, J.; Liang, J.; Mohamed, A.E.; Dong, S.; Tang, C.; Pitschc, H.; et al. Understanding the antagonistic effect of methanol as a component in surrogate fuel models: A case study of methanol/n-heptane mixtures. Combust. Flame 2021, 226, 229-242. [CrossRef]

75. Andersson, J.; Krüger, A.; Grönkvist, S. Methanol as a carrier of hydrogen and carbon in fossil-free production of direct reduced iron. Energy Convers. Manag. 2020, 7, 0051. [CrossRef]

76. Patel, S.K.S.; Gupta, R.K.; Lee, J.K. Integrating anaerobic digestion of potato peels to methanol production by methanotrophs immobilized on banana leaves. Bioresour. Technol. 2021, 323, 4550. [CrossRef]

77. Cantera, S.; Andrea, I.S.; Lebrero, R.; Encina, P.A.G.; Stams, A.J.M.; Muñoz, R. Multi-production of high added market value metabolites from diluted methane emissions via methanotrophic extremophile. Bioresour. Technol. 2018, 267, 401-407. [CrossRef] 
78. Fei, Q.; Guarnieri, M.T.; Tao, L.; Laurens, L.M.L.; Dowe, N.; Pienkos, P.T. Bioconversion of natural gas to liquid fuel: Opportunities and challenges. Biotechnol. Adv. 2014, 32, 596-614. [CrossRef] [PubMed]

79. Eggemann, L.; Escobar, N.; Stolten, D.; Burauel, P.; Stolten, D. Life cycle assessment of a small-scale methanol production system: A Power-to-Fuel strategy for biogas plants. J. Clean. Prod. 2020, 271, 2476. [CrossRef]

80. Wei, J.; Feng, H.; Liu, H.; Zhu, H.; Yue, Z.; Yao, M. Analysis of knocking combustion with methanol/iso-octane and ethanol/isooctane blends in a spark-ignition engine. Fuel 2021, 284, 8979. [CrossRef]

81. Wang, C.; Li, Y.; Xu, C.; Badawy, T.; Sahu, A.; Jiang, C. Methanol as an octane booster for gasoline fuels. Fuel 2019, $284,76-84$. [CrossRef]

82. Prasad, B.S.N.; Pandey, J.K.; Kumar, G.N. Impact of changing compression ratio on engine characteristics of an SI engine fueled with equi-volume blend of methanol and gasoline. Energy 2020, 191, 6605.

83. Yilmaz, I.; Taştan, M. Investigation of hydrogen addition to methanol-gasoline blends in an SI engine. Int. J. Hydrog. Energy 2018, 43, 20252-20261.

84. Elfasakhany, A. Investigation on performance and emissions characteristics of an internal combustion engine fuelled with petroleum gasoline and a hybrid methanol-gasoline fuel. Int. J Eng. Tech. 2013, 13, 24-43.

85. Sharma, N.; Patel, C.; Tiwari, N.; Agarwal, A.K. Experimental investigations of noise and vibration characteristics of gasolinemethanol blend fuelled gasoline direct injection engine and their relationship with combustion characteristics. Appl. Therm. Eng. 2019, 158, 3754. [CrossRef]

86. Liu, F.; Hua, Y.; Wu, H.; Lee, C.F.; Shi, Z. Experimental and kinetic studies of soot formation in methanol-gasoline coflow diffusion flames. J. Energy Inst. 2019, 92, 38-50. [CrossRef]

87. Oßwald, P.; Güldenberg, H.; Höinghaus, K.K.; Yang, B.; Yuan, T.; Qi, F. Combustion of butanol isomers-A detailed molecular beam mass spectrometry investigation of their flame chemistry. Combust. Flame 2010, 158, 2-15. [CrossRef]

88. Rochón, E.; Cortizo, G.; Cabot, M.I.; Cubero, M.T.G.; Coca, M.; Ferrari, M.D.; Lareo, C. Bioprocess intensification for isopropanol, butanol and ethanol (IBE) production by fermentation from sugarcane and sweet sorghum juices through a gas strippingpervaporation recovery process. Fuel 2020, 281, 8593. [CrossRef]

89. Singh, V.; Yadav, S.; Sen, R.; Das, D. Concomitant hydrogen and butanol production via co-digestion of organic wastewater and nitrogenous residues. Int. J. Hydrog. Energy 2020, 45, 24477-24490. [CrossRef]

90. Atsumi, S.; Hanai, T.; Liao, J.C. Non-fermentative pathways for synthesis of branched-chain higher alcohols as biofuels. Nature 2008, 451, 86-89.

91. Díaz, V.H.G.; Willis, M.J.; Stosch, M.; Tost, G.O.; Rubio, O.P. Assessing the energy requirements for butanol production using fermentation tanks-in-series operated under vacuum. Renew. Energy 2020, 160, 1253-1264. [CrossRef]

92. Sheng, y.; Wu, J.; Zhao, L.; Wu, C.; Zian, Q.I.; Cao, G. Optimization of Culture Conditions for Enhanced Butanol Production by a High Butanol Tolerant Clostridium Beijerinckii F-6. Energy Procedia 2019, 158, 471-476. [CrossRef]

93. Wu, M.; Wang, M.; Liu, J.; Huo, J. Assessment of potential life-cycle energy and greenhouse gas emission effects from using corn-based butanol as a transportation fuel. Biotechnol. Prog. 2008, 24, 1204-1214. [CrossRef]

94. Farkade, H.S.; Pathre, A.P. Experimental investigation of methanol, ethanol and butanol blends with gasoline on SI engine. Int. J. Emerg. Tech. Adv. Eng. 2012, 2, 205-215.

95. Deng, B.; Yang, J.; Zhang, D.; Feng, R.; Fu, J.; Liu, J.; Li, K.; Liu, X. The challenges and strategies of butanol application in conventional engines: The sensitivity study of ignition and valve timing. Appl. Energy 2013, 108, 248-260. [CrossRef]

96. Deng, B.; Fu, J.; Zhang, D.; Yang, J.; Feng, R.; Liu, J.; Li, K.; Liu, X. The heat release analysis of bio-butanol/gasoline blends on a high speed SI (spark ignition) engine. Energy 2013, 60, 230-241. [CrossRef]

97. Szwaja, S.; Naber, J.D. Combustion of n-butanol in a spark-ignition IC engine. Fuel 2010, 89, 1573-1582. [CrossRef]

98. Elfasakhany, A. Experimental study on emissions and performance of an internal combustion engine fueled with gasoline and gasoline/n-butanol blends. Energy Convers. Manag. 2014, 88, 277-283. [CrossRef]

99. Dernotte, J.; Rousselle, C.M.; Halter, F.; Seers, P. Evaluation of butanol-gasoline blends in a port fuel-injection, spark-ignition engine. Oil Gas Sci. Technol. Rev. 2010, 65, 345-351. [CrossRef]

100. Yang, J.; Yang, X.; Liu, J.; Han, Z.; Zhong, Z. Test Investigations of Gasoline Engine Fueled with Butanol-Gasoline Blends; SAE Technical Paper: Warrendale, PA, USA, 2009; p. 01-1891.

101. Yang, J.; Wang, Y.; Feng, R. The Performance Analysis of an Engine Fueled with Butanol-Gasoline Blend; SAE Technical Paper: Warrendale, PA, USA, 2011; p. 01-1191.

102. Wigg, B.; Coverdill, R.; Lee, C.; Kyritsis, D. Emissions characteristics of neat butanol fuel using a port fuel-injected, spark-ignition engine; SAE Technical Paper: Warrendale, PA, USA, 2011; p. 01-0902.

103. Martin, P.; Martin, M.; Michal, V.L. Effect of Higher Content n-Butanol Blends on Combustion, Exhaust Emissions and Catalyst Performance of an Unmodified SI Vehicle Engine; SAE Technical Paper: Warrendale, PA, USA, 2012; p. 01-1594.

104. Dagaut, P.; Togbe, C. Oxidation kinetics of butanol-gasoline surrogate mixtures in a jet-stirred reactor: Experimental and modeling study. Fuel 2008, 87, 3313-3321. [CrossRef]

105. Dagaut, P.; Togbe, C. Experimental and modeling study of the kinetics of oxidation of butanol-n-heptane mixtures in a jet-stirred reactor. Energy Fuel 2009, 23, 3527-3535. [CrossRef]

106. Venugopal, T.; Ramesh, A. Experimental studies on the effect of injection timing in a SI engine using dual injection of n-butanol and gasoline in the intake port. Fuel 2014, 115, 295-305. [CrossRef] 
107. Yacoub, Y.; Bara, R.; Gautam, M. The performance and emission characteristics of C1-C5 alcohol-gasoline blends with matched oxygen content in a single cylinder spark ignition engine. Proc. Inst. Mech. Eng. Part A Power Energy 1998, 212, 363-379. [CrossRef]

108. Gu, X.; Huang, Z.; Cai, J.; Gong, J.; Wu, X.; Lee, C.F. Emission characteristics of a spark-ignition engine fuelled with gasoline-nbutanol blends in combination with EGR. Fuel 2012, 93, 611-617. [CrossRef]

109. Park, S.; Kim, H.; Choi, B. Emission characteristics of exhaust gases and nanoparticles from a diesel engine with biodiesel-diesel blended fuel (BD20). J. Mech. Sci. Technol. 2009, 23, 2555-2564. [CrossRef]

110. Cairns, A.; Stansfield, P.; Fraser, N.; Blaxill, H.; Gold, M.; Rogerson, J.; Goodfellow, C. A Study of Gasoline-Alcohol Blended Fuels in an Advanced Turbocharged DISI Engine; SAE Technical Paper: Warrendale, PA, USA, 2009; p. 01-0138.

111. Niass, T.; Amer, A.A.; Xu, W.; Vogel, S.R.; Hortmann, K.K.; Adomeit, P.; Brassat, A. Butanol Blending-A Promising Approach to Enhance the Thermodynamic Potential of Gasoline-Part 1; SAE Technical Paper: Warrendale, PA, USA, 2011; p. 01-1990.

112. Gautam, M.; Martin, D.W. Combustion characteristics of higher alcohol/gasoline blends. Proc. Inst. Mech. Eng. 2000, $214,497-511$. [CrossRef]

113. Gautam, M.; Martin, D.W. Emission characteristics of higher-alcohol/gasoline blends. Proc. Inst. Mech. Eng. 2000, $214,165-182$. [CrossRef]

114. Williams, J.; Goodfellow, C.; Lance, D.; Ota, A.; Nakata, K.; Kawatake, K. Impact of Butanol and Other Bio-Components on the Thermal Efficiency of Prototype and Conventional Engines; SAE Technical Paper: Warrendale, PA, USA, 2009; p. 01-1908.

115. Cooney, C.; Wallner, T.; McConnell, S.; Gillen, J.C.; Abell, C.; Miers, S.A. Effects of Blending Gasoline With Ethanol and Butanol on Engine Efficiency and Emissions Using a Direct-Injection, Spark-Ignition Engine. In Proceedings of the ASME 2009 Internal Combustion Engine Division Spring Technical Conference, Milwaukee, Wisconsin, USA, 3-6 May 2009; ICES2009-76155. ASME: Milwaukee, WI, USA, 2009.

116. Mittal, N.; Athony, R.L.; Bansal, R.; Kumar, C.R. Study of performance and emission characteristics of a partially coated LHR SI engine blended with n-butanol and gasoline. Alex. Eng. J. 2013, 52, 285-293. [CrossRef]

117. Pereira, J.S.; Aleiferis, P.G.; Richardson, D.; Wallace, S. Characteristics of Ethanol, Butanol, Iso-Octane and Gasoline Sprays and Combustion from a Multi-Hole Injector in a DISI Engine; SAE Technical Paper: Warrendale, PA, USA, 2008; pp. 01-1591.

118. Broustail, G.; Halter, F.; Seers, P.; Moréac, G.; Rousselle, C.M. Comparison of regulated and non-regulated pollutants with iso-octane/butanol and iso-octane/ethanol blends in a portfuel injection spark-ignition engine. Fuel 2012, 94, 251-261. [CrossRef]

119. Venugopal, T.; Ramesh, A. Effective utilisation of butanol along with gasoline in a spark ignition engine through a dual injection system. Appl. Therm. Eng. 2013, 59, 550-558. [CrossRef]

120. Broustail, G.; Seers, P.; Halter, F.; Moréac, G.; Rousselle, C.M. Experimental determination of laminar burning velocity for butanol and ethanol isooctane blends. Fuel 2011, 90,1-6. [CrossRef]

121. Lavoie, G.A.; Blumberg, P.N. A fundamental model for predicting fuel consumption, NOx and HC emissions of the conventional spark-ignited engine. Combust. Sci. Technol. 1980, 21, 225-258. [CrossRef]

122. Hu, E.J.; Huang, Z.H.; Liu, B.; Zheng, J.J.; Gu, X.L. Experimental study on combustion characteristics of a spark-ignition engine fueled with natural gas-hydrogen blends combining with EGR. Int. J. Hydrog. Energy 2009, 34, 1035-1044. [CrossRef]

123. Heywood, J.B. Internal Combustion Engine Fundamentals; McGraw-Hill: New York, NY, USA, 1988; ISBN 978-0070286375.

124. Wallner, T.; Miers, S.A.; McConnell, S. A comparison of ethanol and butanol as oxygenates using a direct-injection, spark-ignition engine. J. Eng. Gas Turb. Power 2009, 131, 1-9. [CrossRef]

125. Feng, R.; Yang, J.; Zhang, D.; Deng, B.; Fu, J.; Liu, J.; Liu, X. Experimental study on SI engine fuelled with butanol-gasoline blend and H2O addition. Energy Convers Manag. 2013, 74, 192-200. [CrossRef]

126. Wigg, B.R. A Study on the Emissions of Butanol Using a Spark Ignition Engine and Their Reduction Using Electrostatically Assisted Injection. Master's Thesis, University of Illinois at Urbana-Champaign, Urbana, IL, USA, 2011.

127. Elfasakhany, A. Experimental investigation on SI engine using gasoline and a hybrid iso-butanol/gasoline fuel. Energy Convers Manag. 2015, 95, 398-405. [CrossRef]

128. Irimescu, A. Performance and fuel conversion efficiency of a spark ignition engine fueled with iso-butanol. Appl. Energy 2012, 96, 477-483. [CrossRef]

129. Alasfour, F.N. Butanol-A single-cylinder engine study: Availability analysis. Appl. Therm. Eng. 1997, 17, 537-549. [CrossRef]

130. Alasfour, F.N. Nox emission from a spark ignition engine using 30\% iso-butanol/gasoline blend: Part 2-Ignition timing. Appl. Therm. Eng. 1998, 18, 609-618. [CrossRef]

131. Alasfour, F.N. Effect of using 30\% iso-butanol-gasoline blend on hydrocarbon emissions from a spark-ignition engine. Energy Sources 1999, 21, 379-394. [CrossRef]

132. Kelkar, A. Comparative Study of Methanol, Ethanol, Isopropanol and Butanol as Motor Fuels, Either Pure or Blended with Gasoline. Master's Thesis, South Dakota State University, Brookings, SD, USA, 1988.

133. Bata, R.; Elrod, A.; Lewandowski, T. Evaluation of butanol as an alternative fuel. In Proceedings of the Energy-Sources Technology Conferences and Exhibition, Houston, TX, USA, 22-25 January 1989.

134. Rice, R.W.; Sanyal, A.K.; Elrod, A.C.; Bata, R. Exhaust-gas emissions of butanol, ethanol, and methanol-gasoline blends. J. Eng. Gas Turbines Power 1991, 113, 377-381. [CrossRef]

135. He, B.Q.; Wang, X.; Hao, M.; Yan, G.; Xiao, H. A study on emission characteristics of an EFI engine with ethanol blended gasoline fuels. Atmos. Environ. 2003, 37, 949-957. [CrossRef] 
136. Chang, Y.C.; Lee, W.J.; Lin, S.L.; Wang, L.C. Green energy: Water-containing acetone-butanol-ethanol diesel blends fueled in diesel engines. Appl. Energy 2013, 109, 182-191. [CrossRef]

137. Chang, Y.C.; Lee, W.J.; Wu, T.S.; Wu, C.Y.; Chen, S.J. Use of water containing acetone-butanol-ethanol for NOx-PM (nitrogen oxide-particulate matter) trade-off in the diesel engine fueled with biodiesel. Energy 2014, 64, 678-687. [CrossRef]

138. Lin, S.L.; Lee, W.J.; Lee, C.F.; Chen, S.J. Energy savings and emission reduction of nitrogen oxides, particulate matter, and polycyclic aromatic hydrocarbons by adding water-containing acetone and neat soybean oil to a diesel-fueled engine generator. Energy Fuels 2010, 24, 4522-4533. [CrossRef]

139. Elfasakhany, A. Performance and emissions analysis on using acetone-gasoline fuel blends in spark-ignition engine. Eng. Sci. Tech. JESTECH 2016, 19, 1224-1232. [CrossRef]

140. Chen, R.H.; Chiang, L.B.; Wu, M.H.; Lin, T.H. Gasoline displacement and NOx reduction in an SI engine by aqueous alcohol injection. Fuel 2010, 89, 604-610. [CrossRef]

141. Liaquat, A.M.; Kalam, M.A.; Masjuki, H.H.; Jayed, M.H. Potential emissions reduction in road transport sector using biofuel in developing countries. Atmos. Environ. 2010, 44, 3869-3877. [CrossRef]

142. Srinivasan, C.; Saravanan, C.G. Study of combustion characteristics of an SI engine fuelled with ethanol and oxygenated fuel additives. J. Sustain. Energy Environ. 2010, 1, 85-91.

143. Irimescu, A. Fuel conversion efficiency of a port injection engine fueled with gasoline-isobutanol blends. Energy 2011, 36, 3030-3035. [CrossRef]

144. Abdehagh, N.; Tezel, F.H.; Thibault, J. Separation techniques in butanol production: Challenges and developments. Biomass Bioenergy 2014, 60, 222-246. [CrossRef]

145. Gu, X.; Li, Q.; Huang, Z. Laminar burning velocities and flame instabilities of butanol isomers-air mixtures. Comb. Flame 2010, 157, 2318-2325. [CrossRef]

146. Balat, M.; Balat, H.; Öz, C. Progress in bioethanol processing. Prog. Energy Comb. Sci. 2008, 34, 551-573. [CrossRef]

147. Szukzyk, K.R. Which is better transportation fuel-butanol or ethanol? Int. J. Energy Environ. 2010, 1, 501-512.

148. Elfasakhany, A. Investigations on performance and pollutant emissions of spark-ignition engines fueled with n-butanol-, isobutanol-, ethanol-, methanol-, and acetone-gasoline blends: A comparative study. Renew. Sustain. Energy Rev. 2017, 71, 404-413. [CrossRef]

149. Elfasakhany, A. Gasoline engine fueled with bioethanol-bio-acetone-gasoline blends: Performance and emissions exploration. Fuel 2020, 274, 7825. [CrossRef]

150. Elfasakhany, A. Dual and Ternary Biofuel Blends for Desalination Process: Emissions and Heat Recovered Assessment. Energies 2021, 14, 61. [CrossRef]

151. Elfasakhany, A. Performance and emissions of spark-ignition engine using ethanol-methanol-gasoline, n-butanol-iso-butanolgasoline and iso-butanol-ethanol-gasoline blends: A comparative study. Eng. Sci. Tech. JESTECH 2016, 19, 2053-2059. [CrossRef]

152. Elfasakhany, A. Exhaust emissions and performance of ternary iso-butanol-bio-methanol-gasoline and n-butanol-bio-ethanolgasoline fuel blends in spark-ignition engines: Assessment and comparison. Energy 2018, 158, 830-844. [CrossRef]

153. Elfasakhany, A. Investigations on the effects of ethanol-methanol-gasoline blends in a spark-ignition engine: Performance and emissions analysis. Eng. Sci. Tech. JESTECH 2015, 18, 713-719.

154. Elfasakhany, A.; Mahrous, A.F. Performance and emissions assessment of n-butanol-methanol-gasoline blends as a fuel in spark-ignition engines. Alex. Eng. J. 2016, 55, 3015-3024. [CrossRef]

155. Balaji, D.; Govindarajan, P.; Venkatesan, J. Influence of isobutanol blend in spark ignition engine performance operated with gasoline and ethanol. Int. J. Eng. Sci. Tech. 2010, 2, 2859-2868.

156. Siwale, L.; Kristóf, L.; Bereczky, A.; Mbarawa, M.; Kolesnikov, A. Performance, combustion and emission characteristics of n-butanol additive in methanol-gasoline blend fired in a naturally-aspirated spark ignition engine. Fuel Proc. Tech. 2014, 118, 318-326. [CrossRef]

157. Nazzal, I.T. Experimental study of gasoline-Alcohol blends on performance of internal combustion engine. Eur. J. Sci. Res. 2011, $52,16-22$.

158. Elfasakhany, A. Experimental study of dual n-butanol and iso-butanol additives on spark-ignition engine performance and emissions. Fuel 2016, 163, 166-174. [CrossRef]

159. Elfasakhany, A. Engine performance evaluation and pollutant emissions analysis using ternary bio-ethanol-iso-butanol-gasoline blends in gasoline engines. J. Clean. Prod. 2016, 139, 1057-1067. [CrossRef]

160. Minato, R. Advantage of ethanol fuel for gas generator cycle air turbo ramjet engine. Aerosp. Sci. Technol. 2016, 50, 161-172. [CrossRef]

161. Liu, Y.; Li, G.; Chen, Z.; Shen, Y.; Zhang, H.; Wang, S.; Qi, J.; Zhu, Z.; Wang, Y.L.; Gao, J. Comprehensive analysis of environmental impacts and energy consumption of biomass-to-methanol and coal-to-methanol via life cycle assessment. Energy 2020, $204,7961$. [CrossRef]

162. Veza, I.; Said, M.F.M.; Latiff, Z.A. Recent advances in butanol production by acetone-butanol-ethanol (ABE) fermentation. Biomass Bioenergy 2021, 144, 5919. [CrossRef]

163. Wang, Y.; Hu, L.L.L.; Zhuang, L.; Lu, J.; Xu, B. A feasibility analysis for alkaline membrane direct methanol fuel cell: Thermodynamic disadvantages versus kinetic advantages. Electrochem. Commun. 2003, 5, 662-666.

164. Elfasakhany, A. Biofuels in Automobiles: Advantages and Disadvantages: A Review. Curr. Altern. Energy 2019, 3, 1-7. [CrossRef] 
165. Maclean, H.L.; Lave, L.B. Evaluating automobile fuel/propulsion system technologies. Prog. Energy Combust. Sci. 2003, 29, 1-69. [CrossRef]

166. Alasfour, F.N. Nox emission from a spark ignition engine using $30 \%$ iso-butanol/gasoline blend: Part 1 -Preheating inlet air. Appl. Therm. Eng. 1998, 18, 245-256. [CrossRef]

167. Deng, J.; Wang, X.; Wei, Z.; Wang, L.; Wang, C.; Chen, Z. A review of NOx and SOx emission reduction technologies for marine diesel engines and the potential evaluation of liquefied natural gas fuelled vessels. Sci. Total Environ. 2021, 766, 4319. [CrossRef]

168. Buttes, A.G.; Jeanneret, B.; Kéromnès, A.; Moyne, L.; Pélissier, S. Energy management strategy to reduce pollutant emissions during the catalyst light-off of parallel hybrid vehicles. Appl. Energy 2020, 266, 4866.

169. Kozina, A.; Radica, G.; Nižetić, S. Analysis of methods towards reduction of harmful pollutants from diesel engines. J. Clean. Prod. 2020, 262, 1105. [CrossRef]

170. Elfasakhany, A. Reducing automobile pollutant emissions and re-using some of such emissions as a fuel. Ciência Técnica. J. 2017, 32, 160-176.

171. Elfasakhany, A.; Alsehli, M.; Saleh, B.; Aly, A.A.; Bassuoni, M. Renewable Pulverized Biomass Fuel for Internal Combustion Engines. Processes 2020, 8, 465. [CrossRef] 